\title{
Child Labor and the Labor Supply of Other Household Members: Evidence from 1920 America
}

Marco Manacorda

November 2003 


\begin{abstract}
This paper analyses the effect of child labor on household labor supply using 1920 US Census micro data. The aim of the analysis is to understand who in the household benefits from child labor. In order to identify a source of exogenous variation in child labor I use State-specific child labor laws. I find that a rise in the proportion of working children by household is associated with no variation in parents' labor supply. I also find a strong negative externality among children: as the proportion of working children by household rises, everything else equal, the probability that each child works falls while the probability that he attends school rises. This suggests that parents redistribute entirely the returns from child labor to the children in the household, consistent with a model of household labor supply with fully altruistic parents.
\end{abstract}

Keywords: Child labor, child labor laws, household labor supply

JEL codes: J22, J13, K31, N12

This paper was produced as part of the Centre's Labour Markets Programme

\title{
Acknowledgements
}

I am grateful to Tim Besley, David Card, Jan Eeckhout, Erica Field, Maia Guell, Alan Manning, Steve Pischke, Matthew Rabin and participants at a number of university seminars and conference presentations for comments and suggestions. I am also indebted to Adriana Lleras-Muney for making her data on child labor and compulsory schooling laws available and for clarifying some details of these laws. Financial support from the Nuffield Foundation (New Career Development Fellowship in the Social Sciences) and ESRC (grant no. 00022-0131) is very gratefully acknowledged. Address for correspondence: Centre for Economic Performance, London School of Economics, Houghton Street, WC2A 2AE, London, GB. m.manacorda@1se.ac.uk

Marco Manacorda is a member of the Department of Economics, Queen Mary University of London, and an affiliate of the Centre for Economic Performance and STICERD, London School of Economics.

Published by

Centre for Economic Performance

London School of Economics and Political Science

Houghton Street

London WC2A $2 \mathrm{AE}$

All rights reserved. No part of this publication may be reproduced, stored in a retrieval system or transmitted in any form or by any means without the prior permission in writing of the publisher nor be issued to the public or circulated in any form other than that in which it is published.

Requests for permission to reproduce any article or part of the Working Paper should be sent to the editor at the above address.

(C) Marco Manacorda, submitted 2003

ISBN 0753016680

Individual copy price: $£ 5$ 


\section{Child Labor and the Labor Supply of Other \\ Household Members: Evidence from 1920 America}

\section{Marco Manacorda}

Introduction

1. Descriptive evidence: labor markets, child labor and child labor laws in 1920 America

1.1 The background

1.2 Children's and parents' labor force participation

1.3 Children's labor force participation and child labor laws

2. Empirical strategy

3. Regression results

3.1 The effect of child labor laws on children's labor supply

3.2 The effect of child labor on household labor supply

4. Sensitivity analysis

$\begin{array}{lll}4.1 & \text { State-specific age participation profiles } & 34\end{array}$

4.2 Compulsory schooling laws 35

$\begin{array}{lll}4.3 & \text { Gender differences in child labor } & 37\end{array}$

4.4 The allocation of time between the market and the farm 38

$\begin{array}{lll}4.5 & \text { One child households } & 39\end{array}$

5. Conclusions 39

$\begin{array}{ll}\text { References } & 42\end{array}$

$\begin{array}{ll}\text { Appendix } & 45\end{array}$

Tables $\quad 50$

Table A1

Figure $\quad 58$

$\begin{array}{ll}\text { Figure A1 } & 59\end{array}$

The Centre for Economic Performance is financed by the Economic and Social Research Council 


\section{$\underline{\text { Introduction }}$}

In this paper I explore the effect of a rise in children's labor market participation on household labor supply in 1920 America. I use the labor supply responses of different household members to changes in the proportion of working children in the household to infer the degree of parents' altruism towards their children. In order to identify the effect of arguably exogenous changes in child labor I use Statespecific child labor laws.

The assumption that parents are altruistic towards their children goes mainly unchallenged in the recent theoretical literature on child labor (e.g. Basu and Van 1998; Baland and Robinson, 2000). However, the empirical evidence on parents' altruism is mixed. Altonji et al. (1997), for example, find only a modest degree of parental altruism in contemporary America, and Parson and Goldin (1989) come to a similar conclusion for 1900 America. Using micro data on working-class families, these authors find little evidence that working children benefit from the returns from their work, either in the form of retained earnings or in the form of accumulated household wealth. Parental exploitation might therefore be at the root of individuals' poor human capital accumulation, and policy interventions (in the form, for example, of child labor laws) might be desirable if child labor is associated with some inefficiently low level of education or if the social planner cares about the well-being of children. By the same token, if parents are selfish, policies such as unconditional income transfers to parents might be of little help in curbing child labor and increasing children's schooling. This might explain the success of policies such as Progresa in Mexico, Bolsa Escola in Brazil and Food for Education in Bangladesh that make income transfers to poor households conditional on children's school attendance.

In this paper I propose an empirical strategy aiming at uncovering parents' preferences for their children's well-being and ultimately testing whether parental exploitation is at the root of child labor. I do so by investigating who in the household benefits, in terms of increased consumption of leisure (or 
schooling), from the additional resources accruing to the household from child labor. I work under (what I believe to be) the reasonable assumption that it is parents who decide about their own and their children's labor supply. In order to perform my test, I first examine whether parents adjust their labor supply as the proportion of working children in the household rises. While, obviously, the fact that children work is not by itself a sign of parental selfishness, the fact that parents do not work while their children do implies that parents privately benefit from child labor. In turn, this suggests that parents are not fully altruistic towards their children and therefore that exploitation is (in part) at the root of child labor. ${ }^{1}$ I then investigate whether there is any externality stemming from child labor, i.e. whether and to what extent it is children - whether working or not - who benefit from such additional resources available to the household. I do so by examining whether, everything else being equal, each child in the household is less likely to work or more likely to go to school as the proportion of working children by household rises. Again I use this analysis to make some inference on parental altruism since I interpret the effect of this externality as an indication of whether parents redistribute such additional resources among children.

One difficulty in trying to identify household labor supply responses to changes in child labor is that the labor supply decisions of all individuals in the household are likely to be simultaneously taken by parents. This induces some spurious correlation between the labor supply of children and the labor supply of their parents and siblings that has nothing to do with the causal effect of child labor on other household members' labor supply.

In order to identify an arguably exogenous source of variation in children's labor supply I use State-specific child labor laws in force in 1920 America. By then most US States had child labor laws.

\footnotetext{
${ }^{1}$ There is no doubt that parents are to some extent altruistic towards their children. The point though is whether they are or not fully altruistic, i.e. whether they care infinitely more about their children's well-being compared to their own.
} 
In addition, while there is evidence that prior to then child labor laws had little effect, there is some consensus that by the early 1900s child labor laws had a significant effect on children's participation (and schooling), so one can try to use child labor laws as a source of variation in child labor. Obviously, though, for child labor laws to be a good instrument for children's labor force participation one has to check that these can be legitimately excluded from the labor supply equations of other household members, so I discuss this issue at some length in the paper.

The structure of the paper is as follows. Section 1 introduces the data and presents some descriptive evidence on household labor supply in 1920 America and on the effect of child labor laws on children's labor force participation. Section 2 presents the empirical strategy. A theoretical model underlying this empirical strategy is presented in the Appendix. Section 3 presents the regression results and Section 4 presents a variety of robustness checks. Section 5 concludes.

\section{Descriptive evidence: labor markets, child labor and child labor laws in 1920 America}

\section{$\underline{1.1 \text { The background }}$}

The first decades of the last century saw a massive transformation of the American economy and society (Goldin 1996; Goldin and Katz 1996, 1998). This was the period when the automobile, office equipment, commercial radio and electrical household appliances entered the life of ordinary Americans. Manufacturing, by far the most important sector of the economy, was undergoing profound changes: the availability of new technologies and, in particular, of purchased electrical horsepower paved the way for the passage from the traditional factory (assembly line) to continuous and batch 
production processes. This change in production technology was associated with a tremendous rise in the demand for skilled labor. ${ }^{2}$

Changes in the labor market took place not only on the demand side but also on the supply side. Immigration (especially of unskilled workers) boomed in the first decades of the century until the onset of World War I. Also, and arguably as a partial consequence of the rise in the demand for skills, the decades from 1910 to 1930 saw an unprecedented rise in high school attendance and graduation of young Americans. The high school movement was the greatest transformation of the American education system: new schools were built, school districts were consolidated and curricula were changed to meet the demands of a middle class increasingly willing to enter the labor market after completion of high school (Goldin 1998, 1999a). ${ }^{3}$

The interplay between the demand for skills and the supply of skills was crucial in shaping the outcomes in the labor market (Goldin, 1999b; Goldin and Katz, 1997). The evidence that exists suggests that skill premia were high in the early $1910 \mathrm{~s} .{ }^{4}$ High returns to education prompted an increase in the demand for schooling, which, in turn, lowered returns through the increase in the supply of skilled labor. ${ }^{5}$ Between 1920 and 1940 high school graduation and enrollment rose dramatically but

\footnotetext{
${ }^{2}$ This change contrasted with the first transformation of the American manufacturing sector (from the artisan shop to the factory) that took place during the $19^{\text {th }}$ century and that brought about a rise in the demand for unskilled labor. Goldin and Sokoloff (1982) examine the rise and fall of child (and female) employment in manufacturing during the first half of the $19^{\text {th }}$ century. They argue that employment of children in manufacturing peaked somewhere in the first half of that century (between the late 1830s and the early 1840s) and they track down this movement to a rise in demand for unskilled labor linked to general technical progress and to the increase in the share of manufacturing over total output. For a fascinating analysis of child labor in $19^{\text {th }}$ century America see also Willoughby (1890).

3 There were pronounced differences across regions in the impetus of the high school movement. Expansion was particularly rapid in the non-south. By contrast, the movement towards the abolition of child labor was largely opposed by Southern capitalists who still employed cheap labor in agriculture well into the beginning of the $20^{\text {th }}$ century. A separate issue regards blacks who were concentrated in the South. Almost all black children attended segregated schools (Boozer et al., 1992) and the quality of the education they received was lower than that of whites (Card and Krueger, 1992).

${ }^{4}$ Goldin and Katz (2000) based on data from Iowa estimate that the return to an additional year of high school and college for young male workers was about $12 \%$ in 1915.

${ }^{5}$ Differentials fell somewhat during World War I, perhaps as a consequence of the rise in the demand for unskilled labor in the war period.
} 
returns stayed roughly constant, suggesting that changes in the relative supply of skills kept pace with the rise in relative demand prompted by technological change.

The tremendous rise in school attainment was associated with a fall in the employment of children, especially in manufacturing. Although there is some disagreement as to when exactly child labor reversed its trend, certainly the decade between 1910 and 1920 was one of rapidly decreasing labor force participation of children. ${ }^{6}$

At the same time, the first two decades of the century saw the rise of a strong movement advocating more stringent child labor legislation (Trattner, 1970). Although originally prompted by few social reformers and philanthropists, the movement against child labor soon encountered the consensus of the middle class. Civic participation was at its highest over the century, ${ }^{7}$ and the middle class, helped by widespread propaganda, started to recognize the benefits of schooling and the 'evils' of child labor. The decade between 1910 and 1920 is probably the one where the most progress was made in terms of child labor legislation. ${ }^{8}$ By 1920 all States had compulsory schooling laws and child labor legislation (in various forms). Enforcement was stricter than ever before, possibly also a reflection of the change in people's attitudes and the increased pressure by the Federal Government. Indeed, the existing evidence suggests that child labor laws in force over this period had a non negligible effect on the educational attainment of the cohorts who were exposed to them (Margo and Finegan, 1996; Acemoglu

\footnotetext{
${ }^{6}$ Trattner (1970) claims that between 1910 and 1920 the number of children aged 10-15 involved in gainful occupations fell from about 2 millions to around 1 million. Note, however, that after WWI the US entered into a recession with unemployment rising to a level estimated between $8.7 \%$ and $11.7 \%$. Also, data from 1910 are not strictly comparable to data from the 1920 census since the former was conducted in April while the latter in January (a period in which agriculture is at a standstill).

${ }^{7}$ Putnam (2000) reports that civic participation was higher in the first decades of the last century than in any other period after that.

${ }^{8}$ Although later declared unconstitutional by the Supreme Court, two Federal laws were passed in 1916 and 1919 that greatly limited the employment of children under age 14 and restricted employment in several industries and occupations. Both laws prohibited employment of children under fourteen in mills, canneries, workshops or factories and employment of children under sixteen in mines or quarries (Fuller, 1922).
} 
and Angrist 2000; Lleras-Muney, 2002). The experience of the 1910s contrasted with the experience of the previous decades: in late $19^{\text {th }}$ century America child labor legislation was not uniform across States and was poorly enforced. ${ }^{9} 10$

\subsection{Children's and parents' labor force participation}

In order to investigate the effect of child labor laws on children's labor force participation, I integrate the micro data of the 1920 US census with data on State child labor laws. The 1920 Census provides detailed information on the usual occupation and industry of employment of individuals aged 10 or more. ${ }^{11}$ One drawback of the data, however, is that no information on work intensity (whether hours, days, weeks or months of work) was collected. In addition, the Census provides no information on wages or income, whether from labor or other sources. Child labor laws in this paper refer to minimum working age, i.e. the minimum age at which a child could obtain a work permit in his State of residence. ${ }^{12}$

\footnotetext{
${ }^{9}$ The evidence on the effect of child labor and compulsory schooling legislation on labor market participation of young Americans up to 1920 is mixed. Moehling (1999) finds little effect of child (manufacturing) labor laws on child work in turn of the century America. Her analysis though stops in 1910 and indeed she finds a stronger effect for the decade after the turn of the century than for the period preceding it. Margo and Finegan (1996) find a strong effect of compulsory schooling laws when used in conjunction with child labor laws on school attendance of 14-year olds in 1900 America.

${ }^{10}$ There is some dispute in the literature as to whether child labor and compulsory schooling legislation contributed to the fall in child labor force participation or whether legislation only embodied ex-post the changes that had occurred in the labor market. A view that is generally held is that legislation followed suit the great transformation of the American economy: the fall in the relative importance of agriculture, the transformation of manufacturing with the associated rise in the demand for skills, the rise in the supply of unskilled labor brought about by immigration, the secular increase in standards of living and the increased availability of educational opportunities (Sanderson, 1974; Landes and Solmon, 1972. This view is also reported in many of Goldin's papers quoted above). Lleras-Muney (2002), though, suggests that State-specific child labor laws in force from 1915 onwards were largely uncorrelated with observed State characteristics.

${ }^{11}$ The concept of unemployment did not exist at that time. Individuals were classified according as to whether they had a gainful occupation or not.

${ }^{12}$ My sample only refers to the 48 mainland States with the exclusion of the District of Columbia. Census data come from IPUMS (www.ipums.org). Data from child labor laws are the ones collected by Adriana Leeras-Muney and are available on her website (http://www.princeton.edu/ alleras/papers.htm). The dataset has no information prior to 1915, which obviously rules out using the 1910 Census. The following available Census is in 1940, a time when child labor had almost disappeared in the US. States had different provisions against child labor: the legislation set minimum working ages, prohibited employment in some occupations, set restrictions on working hours or specified educational requirements for employment.
} 
From now on, I classify individuals aged $10-16$ as children. ${ }^{13}$ Because I am interested in the effect of child labor laws on the labor supply of different household members, I restrict the sample to children living with both parents. ${ }^{14}$ Also, in order to minimize the probability that older children of the parents live outside the household, which might induce a spurious correlation between the labor supply of the child and the labor supply of other members of the household, I restrict the sample to children whose mother is aged $25-41$ and whose father is aged $25-66 .{ }^{15}$ Finally, I exclude households with members other than cohabiting children aged 10-16 and their parents. This avoids the complication of having to model simultaneously the labor supply of children and their parents together with the labor supply of other household members. This gives an overall sample of 44,402 children in 26,612 households. $^{16}$

\footnotetext{
In this paper I only use data on minimum working age. As a general rule, where different minimum ages were set for different types of child labor, the minimum of these ages in each State has been used (personal communication to Adriana Lleras-Muney).

${ }^{13}$ It is not obvious what the maximum age for child labor should be. For the purpose of child labor, the ILO includes among children those aged up to 14 or 15 . Perhaps the model in the Appendix suggests that - if one had such a measure -working children should be the ones whose labor supply choices are taken by parents. I include children up to age 16 in order to maintain a relatively large sample and exploit the variation coming from child labor laws.

${ }^{14} 89 \%$ of children aged $10-16$ are classified as children of the head of the household. Less than $0.5 \%$ are classified as heads or spouses. Since in order to link children to their parents I use the imputed relation variable that is available in the IPUMS, I also exclude children living with their parents but for whom no imputed relation can be detected.

${ }^{15}$ This selection rule is perfect if women have no children before the age of 25 . To check for this, I have examined data from the 1910 census. In Table A1 in the Appendix I report data on the distribution of women born between 1870 and 1885 (and therefore aged between 35 and 50 in 1920) with a child born between 1904 and 1910 (and therefore aged 10-16 in 1920). I exclude women born between 1886 and 1895 (and therefore aged between 25 and 34 in 1920) because imputation of mothers in the household seems to work pretty poorly for very young women (those aged 15-24 in 1910). The first column reports the mother's birth cohort and the second column reports her age in 1920. The third and fourth columns report the cumulative probability of having a cohabiting child born before 1904 (and therefore older than 6 in 1910 and older than 16 in 1920). If children of women born between 1870 and 1885 were all living with their mothers in 1910 (which might be a not too bad assumption) and abstracting from mortality of mothers and children, then the difference between these two columns gives us the cumulative proportion of mothers in each cohort with children older than 16 in 1920 who live outside the household. For mothers born after 1879 (and therefore aged 41 or less in 1920), this difference is around $7 \%$.

${ }^{16}$ This is out of 114,188 available observations on individuals aged 10-16.
} 
Table 1 reports some descriptive statistics on children's work activity by age and sex. The first column reports the proportion of children at work. This refers to usual economic activity. ${ }^{17}$ This includes both work in the market for pay (whether in cash or kind) as well as work in the household enterprise, but excludes household chores in their own home as well as occasional work on the household farm. ${ }^{18}$ In the following two columns I split the data into those classified as performing work

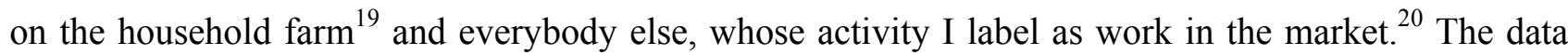
show that participation rises sharply with age, although this rise is more pronounced for boys than for girls. While at age 10 only $3 \%$ of boys and $1.5 \%$ of girls perform some work, participation among 16 year olds is $44 \%$ for boys and $27 \%$ for girls. Among working children, about half work in the market and half work on the household farm, although the age participation profiles differ markedly between the two sectors, possibly a consequence of child labor laws.

\footnotetext{
${ }^{17}$ Individuals in the 1920 census are asked their "Trade, profession, or particular kind of work done [...]". "The entry should $[\ldots]$ indicate the particular kind of work done by which the person enumerated earns money or a money equivalent [...]. Persons [...] may [...] happen to be idle or unemployed at the time of the visit. In such cases the return should be the occupation followed when the person is employed. [...] If a person has two occupations, return only the more important one - that is, the one from which he gets the more money." In this paper, work is defined based on the variable occ1950. A worker is everybody with an occupation code less than 980 (i.e. I exclude the following occupations: Invalid/sick/disabled, Keeps house/house work/housewife, school inmate/prisoner, other non-occupation, N/A).

18 "In the case of a woman doing housework in her own home and having no other employment, the entry [...] should be none. But a woman working at housework for wages should be returned [..,] as housekeeper, servant, or cook, or chambermaid, as the case may be. [...] If a woman, in addition to doing housework in her own home, regularly earns money by some other occupation, whether pursued in her own home or outside, that occupation should be returned [...]. For a woman who works only occasionally, or only a short time each day at outdoor farm or garden work, or in the dairy, or in caring for live stock or poultry, the return should be none; but for a woman who works regularly and most of the time at such work, the return should be farm laborer-home farm; farm laborer-working out; laborer-garden; laborer-dairy farm; laborer-stock farm; or laborer-poultry yard as the case may be. Of course, a woman who herself operates or runs a farm or plantation should be reported as a farmer and not as a farm laborer. In the case of children who work regularly for their own parents on a farm, the entry [...] should be farm laborer but for children who work as farm laborers for others, the entry [...] should be working out. Children who work for their parents at home merely on general household work, on chores, or at odd times on other work, should be reported as having no occupation. Those, however, who somewhat regularly assist their parents in the performance of work other than household work or chores, should be reported as having an occupation."

${ }_{19}$ These are those whose occupation is "Farm laborers, unpaid family workers" or "Farmers" (respectively values 100 and 830 of the variable occ1950).

${ }^{20}$ In practice this category includes also work in the household non-agricultural enterprise.
} 
In the fourth column I report the proportion of those enrolled in school, which comes from the answer to a separate question on the Census form. ${ }^{21}$ School enrollment declines rapidly with age, especially for boys. While around 5\% of both boys and girls aged 10 are out of school, this proportion rises to $46 \%$ for boys and $42 \%$ for girls by age 16 .

Note that the proportions of those enrolled in school and those working do not add up to 100 . In the remaining columns of Table 1 I report the cross-distribution of work and school enrollment. About $6 \%$ of boys and $3 \%$ of girls work while being enrolled in school and about $6 \%$ of boys and $7 \%$ of girls declare neither school enrollment nor a gainful occupation. I classify these children as idle although in reality this category might include those performing household chores plus occasional work on the household farm.

In the following column of Table 1 I report the proportion of children at each age who are legally allowed to work in their State of residence. While less than $4 \%$ of children below age 12 are allowed to work, the corresponding proportion at age 16 is $100 \%$. Note that about $17 \%$ of children live in States with a minimum working age of 12 and around $71 \%$ live in States with a minimum working age of 14. The proportion of working children is well below the proportion of those allowed to work.

In the last column I finally report the proportion of children at each age who are above compulsory schooling age. Note that around $70 \%$ of children live in States with a compulsory schooling age of 16 . No child below age 12 is formally exonerated from school. The data clearly show some non-compliance. For example, at age $115 \%$ of the children fail to report school enrollment

\footnotetext{
${ }^{21}$ This variable records whether the individual attended "school, college, or any educational institution at any time since September 1,1919 [...] In the case of a person who is at work and also attends a school or college, enter the occupation followed $[\ldots]$, and indicate the fact of school or college attendance [...]."
} 
despite schooling being compulsory for everybody at that age. However, by age 16 a large proportion of boys and girls are still at school despite being above compulsory schooling age. ${ }^{22}$

Table 2 reports the distribution of parents' work by children's labor force status and the average age of children aged 10 to 16 in the household. The top part of the Table refers to fathers and the bottom one to mothers. Each row of the Table refers to households with different average age of children between 10 and 16 (approximated to the lowest integer). The first column refers to households with no working children, the second to households with at least one working child and the third to the whole set of households in the sample independent of their children's labor force status. The first thing that emerges from the Table is that almost all fathers work. On average just above $1 \%$ of fathers are inactive. A comparison of the first two columns shows that fathers of working children tend to work slightly more than fathers of non-working children. It is hard, however, to detect any pattern of fathers' participation across households with different average age of the children. An analysis of the bottom part of Table 2 reveals some interesting facts on mothers' participation. First, mothers are much less likely to work than their spouses: on average $7 \%$ of mothers work. As children age, mothers are more likely to work: the proportion of working mothers rises from $6 \%$ in households with children aged 10 to $12 \%$ in households with children aged 16 . The proportion of working mothers is remarkably higher among households with working children: in households where at least one child works. Mothers' participation is around $19 \%$ as opposed to a participation rate of less than $6 \%$ in households where

\footnotetext{
${ }^{22}$ It is interesting to note that minimum legal working age is generally below compulsory schooling age and so the proportion legally allowed to work is above the proportion of those above compulsory schooling age at any age. Effectively, several States in 1920 America allowed children to have a work permit before they were over compulsory schooling age. Work permits were generally administered and granted by schools (Angrist and Krueger, 1991). In some of these States a special provision was made for children with a work permit (or exempted from school for other reasons) to attend continuation school up to a certain age. I have also computed (but not reported) the age distribution of children by compulsory schooling age defined as the maximum between compulsory schooling age and continuation age (where available). Although this lowers slightly the proportion of children required to go to school at each age, it makes essentially no difference to the overall picture.
} 
children do not work. A possible explanation for this is that omitted household characteristics (e.g. household income) have a similar effect on mothers' and children's participation: both the mother and the children might be more likely to work in poor households. Note finally that, among working children, the proportion of working mothers tends first to fall and then to rise as their children age, displaying a sort of U-shaped evolution with a minimum at average children's age 13. One possible explanation for this trend is that two forces are at work. On the one hand, mothers of younger children tend to work less, so that participation of mothers rises with children's age. On the other hand, children working at very early ages belong perhaps to extremely poor households, where the mother is also more likely to work, which produces the opposite participation age-profile for mothers. A combination of these two forces is likely to generate the U-shaped trend observed in the Table.

The evidence in Table 2 suggests that a great amount of care has to be exercised in inferring patterns of causality by simply looking at the correlation between parents' and children's labor force participation. Omitted household and individual characteristics as well as changes in preferences and opportunities along the children's and parents' life cycles are all likely to be confounding factors affecting the labor supply of different household members, possibly in a different fashion.

Table 3 reports the top 5 five jobs (i.e. occupation and industry) for children and parents, together with the associated frequencies. Here I restrict the sample to those performing work in the market. Boys are predominantly engaged in manual work in agriculture, mining and the textile industry. They also work as newsboys. Girls are also mainly involved in manual work in the textile and apparel industry but a non-negligible proportion works as domestic servants in other people's homes, as salaried workers in agriculture or as shop assistants. Fathers perform similar jobs to their male children: a substantial proportion works in agriculture and coal mining. Some occupations, however, are specific to male adults. These include manual work in construction and transport as well as shop- 
keeping. A large proportion of mothers work as laundresses and domestic servants in other people's households, while others work in agriculture and the textile and retail industries. The Table suggests that boys tend to take up some jobs that are typically performed by their fathers while girls seem to be concentrated in occupations that are specific to their mothers. Also, as seems reasonable, children seem typically to be engaged in less skilled occupations than their parents.

\section{$\underline{1.3 \text { Children's labor force participation and child labor laws }}$}

I now turn to some descriptive evidence on the effect of child labor laws on children's labor force participation across States with different child labor laws. Before presenting such evidence, it is worth speculating on the likely effects of child labor laws on child labor. In the absence of a minimum working age, child labor force participation is likely to grow with age. First, productivity (and hence the wage) grows with age. Second, parents might value their children's leisure less as they grow up. Both these effects make child labor less likely at early ages. When child labor laws exist, and assuming compliance, one would expect children below legal working age not to work and one would expect a sharp rise in participation as children turn minimum working age, provided child labor laws effectively bite. As children turn legal working age, participation should jump to its desired level, i.e. the one which would have prevailed in the absence of child labor laws. The higher the legal working age, the higher is the gap between actual and desired participation and therefore the bigger the increase in participation one would expect to observe as children turn legal working age. If job search is costly one would expect child labor to converge only gradually towards the desired level.

Note, however, that a second effect might be at work. If minimum working age legislation tends to depress the supply of child labor to the economy, the demand for inputs that are close substitutes for child labor (and hence workers who are just above legal working age) will increase. In this case, child 
labor laws might induce a degree of steepness in the employment age profiles of children above legal working age. Participation should grow faster after legal working age the higher the legal working age, since these children are in higher demand compared to children of the same age living in States with lower legal working age. In principle, participation of children above legal working age in States with higher legal working age might even outperform participation of similar children in States with lower working age. Eventually, though, one would expect employment rates of workers who are not substitutes for child labor to be independent of child labor laws. If child labor laws are not systematically related to the desired level of labor force participation, employment among prime age individuals should be the same across States. ${ }^{23}$

In Figure 1 I report the employment rate by age for individuals aged 10-18 in seven groups of States, which I have classified, based on their minimum working age. ${ }^{24}$ I have superimposed to the actual series a linear spline in age with a kink at the age just below minimum working age. The exact way in which this linear spline is estimated is described in Section 2 where I present my empirical strategy. For now it is interesting to note that this model predicts remarkably well the actual employment series.

The data are consistent with the predictions that I have outlined above. First, children aged less than minimum working age virtually do no work. For example, the employment rate in States with minimum working age of 14 stays flat at around zero until age 13 while in States with minimum

\footnotetext{
23 A further channel through which child labor laws might have an effect on children's participation is through an intertemporal labor supply effect. If children are not allowed to work at early ages, they (their parents) might make up for missed earnings in early years of life by working (making them work) more as they turn legal working age. This introduces an additional degree of steepness in the employment age profile of children.

${ }^{24}$ Here employment includes both market work and work in the household enterprise. See below for a further discussion on these different types of work.
} 
working age of 7 or 8 it tends to increase roughly monotonically with age. ${ }^{25}$ Second, participation starts to increase just after children turn minimum working age. While, for example, labor force participation of children living in States with a minimum working age of 13 tends to grow smoothly from age 13 onwards, for children living in States with a minimum working age of 14 participation increases only after this age. However, there is no discrete jump in employment: entry into work takes place gradually and participation tends to grow more rapidly in States with higher minimum working age. There is evidence that these States tend to catch up, in terms of youth labor force participation, with States where minimum working age is lower, and even to outperform them. Eventually, though, participation in different States converges to a similar level. In Figure A1 in the Appendix I report participation for individuals aged 10-30 in two groups of States which account for almost $90 \%$ of the sample: ${ }^{26}$ those with a minimum working age of 12 and those with a minimum working age of 14 . It is remarkable how labor force participation of children in States with higher legal working age rises rapidly from age 14 onwards, overshoots participation in States with lower legal working age and then decelerates. By age 25 participation tends to be similar across States with different child labor laws. ${ }^{27}$

One last caveat of this analysis regards the possible underreporting of child labor in those States where this was banned. In this case the evidence in Figure 1 has no behavioral content since it only suggests that households did not report the labor of children below legal working age. Possibly, the evidence in Figure A1 speaks against this alternative hypothesis. The observation that older individuals tend to work more the higher the legal working age is hard to reconcile with underreporting, unless one believes that underreporting on the part of younger individuals is associated with overreporting on the

\footnotetext{
${ }^{25}$ Note, however, that, since there are pronounced differences in the number of children living in each of these different groups of States, some caution should be used in making these comparisons.

${ }^{26}$ Here I include all individuals in the sample, independent of their household composition and parents' age.
} 
part of older ones. However, this evidence is far from conclusive and I will try to add more evidence in this direction later on in the paper when I present my regression results.

Summing up, the evidence in Tables 1 to 3 and in Figure 1 reveals some interesting facts. Children's participation increases with age. This is especially true for market work, a likely reflection of the effect of child labor legislation. Obviously, as children age, they are also less likely to attend school. Almost all fathers work irrespective of their children's age and labor market status. Mothers' participation is low but it is substantially higher in households with working children. While one could take this as a suggestion that mothers tend to work more as a result of their children's labor, another possible explanation is that omitted household factors are likely to affect children's and mothers' work in the same direction. I have also shown that child labor laws seem to have a pronounced effect on children's labor force participation by inducing a discontinuity in participation around minimum working age. I will exploit this discontinuity in the next section for the purpose of identifying a source of variation in children's labor supply that is arguably exogenous to omitted characteristics that affect household labor supply.

\section{Empirical strategy}

In this section I propose an empirical strategy aiming at investigating how the returns from child labor are redistributed among different members in the household. Eventually, I plan to uncover whether parental exploitation is at the root of child labor.

Before presenting a formal econometric model, it is worth highlighting the intuition for the empirical strategy I propose below. Although in the popular mind child labor is often associated with

\footnotetext{
${ }^{27}$ Some caution is needed in interpreting these data, since individuals belonging to earlier cohorts might have been exposed to different child labor laws.
} 
parental exploitation, ${ }^{28}$ it obvious that this need not to be the case. Children might work simply because - in the absence of child labor - the household has too few resources to devote to consumption. However, if parents cut their labor supply while their children work this suggests that parents privately benefit from the additional resources available to the household from child labor. In this case one can quite safely conclude that (part of) the explanation for child labor is parental exploitation.

In the Appendix to the paper I present a simple 'dictatorial' model of household labor supply à la Becker (1981) where parents decide about their children's and their own labor supply. I show how one can interpret the effect of child labor on parental labor supply as a measure of parental altruism. I also show how one can derive the econometric model below from this simple theoretical model and how one can map the reduced form parameters estimated below into the structural parameters of this simple labor supply model. ${ }^{29}$

In order to identify the effect of child labor on different household members' labor supply, I start by modeling the labor supply of each individual child in the household. I assume that each child's labor force participation depends on the child's wage rate and on family income. Additionally, the model should allow for differences in preferences across households and across children in the same household. To make the model operational, I model child labor force participation as a linear function of age, child labor laws and State dummies, plus a set of controls. The age term picks up both

\footnotetext{
${ }^{28}$ Effectively, it is likely that working children perform badly paid jobs, sometimes in unhealthy and dangerous conditions. However, this is more likely to be the reflection of their low levels of skills (and hence wages) and the fact that child labor occurs often in violation of laws (and hence with no legal protection), rather than a sign of parental exploitation. There is hardly any doubt that, if given the opportunity, parents of working children would choose better - and especially better paid - jobs for their children.

${ }^{29}$ The model in the Appendix could be easily rephrased so that the time children spend in non productive activities (leisure) is spent in school. Implicit in my conclusion that parents are altruistic is the assumption that parents do not draw any direct utility from a rise in their children's education and therefore, if selfish, they fail to internalize the effect of a rise in their children's future income due to a rise in the education. Although there might be reasons to object to this view, it is probably indisputable that parents mortality as well as the non-enforceability of contracts that bind children to make positive transfers to their parents as they grow up implies that parents are unlikely to fully internalize the effect of a rise in children's education on their future income unless they are altruistic.
} 
differences in the marginal utility of children's leisure as well as differences in their productivity over the life cycle. Child labor laws can be interpreted as picking up some variation in wages. ${ }^{30}$ State dummies account for systematic differences in the participation across States. If $\mathrm{i}$ denotes a generic child in household $\mathrm{H}$ with $\mathrm{N}_{\mathrm{CH}}$ children, $\mathrm{S}$ is the State of residence, I estimate the following equation:

$$
\mathrm{d}_{\mathrm{CiH}}=\beta_{0 \mathrm{C}}+\beta_{1 \mathrm{C}} \mathrm{Age}_{\mathrm{CiH}}+\mathrm{Z}_{\mathrm{CiH}}{ }^{\prime} \beta_{2 \mathrm{C}}+\mathrm{X}_{\mathrm{CiH}}{ }^{\prime} \beta_{3 \mathrm{C}}+\beta_{4 \mathrm{C}} \mathrm{Age}_{\mathrm{CH}}+\mathrm{X}_{\mathrm{CH}}{ }^{\prime} \beta_{5 \mathrm{C}}+\mathrm{X}_{\mathrm{H}}{ }^{\prime} \beta_{6 \mathrm{C}}+\delta_{\mathrm{CS}}+\mathrm{u}_{\mathrm{CiH}}
$$

where $d_{\mathrm{CiH}}$ is a $0 / 1$ variable denoting whether a child participates, Age ${ }_{\mathrm{CiH}}$ denotes the child's age, $\mathrm{Z}_{\mathrm{CiH}}$ denotes the effect of child labor laws, $\mathrm{X}_{\mathrm{CiH}}$ denotes a set of children's characteristics, $\mathrm{X}_{\mathrm{H}}$ are household and parents' characteristics and the variables with the subscript ' $\mathrm{CH}$ ' (and no subscript i) denote averages across children in the same household (i.e. $\mathrm{X}_{\mathrm{CH}}=\Sigma_{\mathrm{i}} \mathrm{X}_{\mathrm{CiH}} / \mathrm{N}_{\mathrm{CH}}$ ). $\delta_{\mathrm{CS}}$ are State fixed effects and $\mathrm{u}_{\mathrm{CiH}}$ is an error term that accounts for differences in child labor force participation stemming from unobserved differences in household resources, tastes and labor market opportunities as well as labor market and measurement error.

If minimum legal working age in State $\mathrm{S}$ is denoted by $\mathrm{L}_{\mathrm{S}}$, I model child labor laws as the difference between the child's age $\mathrm{Age}_{\mathrm{CiH}}$ and the maximum age at which a child is not allowed to work in his State of residence $\left(\mathrm{L}_{\mathrm{S}}-1\right)$. I let this variable be equal to zero if the child is younger than minimum working age in his State of residence. In formulas:

$$
\mathrm{Z}_{\mathrm{CiHS}}=\mathrm{I}\left(\mathrm{Age}_{\mathrm{CiH}}-\mathrm{L}_{\mathrm{S}}+1>0\right)\left(\mathrm{Age}_{\mathrm{CiH}}-\mathrm{L}_{\mathrm{S}}+1\right)
$$

where $\mathrm{I}(\mathrm{)})$ is an indicator function. $\mathrm{Z}_{\mathrm{CiHS}}$ takes value 1 if the child is exactly legal working age, 2 if the child is one year above legal working age, and so on.

\footnotetext{
${ }^{30}$ One way of thinking about child labor laws is that they affect a child's shadow wage. This is the approach used, among others, by Deaton and Muellbauer (1980) in the context of commodity demand with rationing. One can derive a shadow price of leisure, that is the price of leisure under which unconstrained households would chose zero working hours for children. Clearly a wage level that satisfies this property is a wage equal zero. For an analysis of household labor supply with rationing (i.e. involuntary unemployment) see Ashenfelter (1980).
} 
Consistent with the evidence in Figure 1, model (1) postulates that child work varies linearly with age (at a rate $\beta_{1 C}$ ) but it accelerates after a child turns legal working age $L_{S}$ and rises then at higher speed. ${ }^{31}$ The increase in the steepness of the age profile is picked up by the term $\beta_{2 \mathrm{C}}$ : this reflects the effect of child labor laws. I let the coefficient $\beta_{1 \mathrm{C}}$ be the same across different States. Although this is not necessary for my identification, this has the advantage of making the analysis more intelligible. In section 4 I will remove this hypothesis and show how my results are unchanged when a less parsimonious model is used. I let instead $\beta_{2 \mathrm{C}}$ vary by minimum working age so that $\mathrm{Z}_{\mathrm{CiH}}$ is effectively a vector with 7 elements (i.e. as many as the different minimum working ages: 0, 7, 8, 12, 13, 14 and 15). Based on the discussion in Section 1, I expect $\beta_{2 \mathrm{C}}$ to grow with $\mathrm{L}_{\mathrm{S}}$. State fixed effects $\delta_{\mathrm{CS}}$ pick up average differences in child labor participation across States. Effectively, in the absence of further controls, this model corresponds to the linear spline I have fitted to the data in Figure 1.

I now examine parents' behavioral responses to changes in child labor. To do so, I assume that, conditional on a number of covariates, parents' labor force participation is a function of the average participation of children in the household:

$$
\mathrm{d}_{\mathrm{PH}}=\beta_{0 \mathrm{P}}+\phi_{\mathrm{P}} \mathrm{d}_{\mathrm{CH}}+\beta_{4 \mathrm{P}} A \mathrm{ge}_{\mathrm{CH}}+\mathrm{X}_{\mathrm{CH}} \beta_{5}+\mathrm{X}_{\mathrm{H}}{ }^{\prime} \beta_{6}+\delta_{\mathrm{PS}}+\mathrm{u}_{\mathrm{PH}}
$$

where $\mathrm{d}_{\mathrm{CH}}$ is the proportion of working children in the household (i.e. $\mathrm{d}_{\mathrm{CH}}=\Sigma_{\mathrm{i}} \mathrm{d}_{\mathrm{CiH}} / \mathrm{N}_{\mathrm{CH}}$ ). The coefficient $\phi_{\mathrm{P}}$ picks us the effect of increased children's labor force participation on parents' labor supply. If one assumes that the household utility function is separable in the leisure of different household members, this coefficient picks up (some transformation of) the income effect arising from changes in children's labor force participation on parents' labor supply. If parents 'exploit' their children one would expect $\phi_{\mathrm{P}}$ to be negative since in this case a rise in children's labor supply is associated with a fall in parents'

\footnotetext{
${ }^{31}$ The model therefore allows for work to be performed before minimum working age, possibly because of non-compliance.
} 
labor supply. If parents do not appropriate the returns from child labor $\phi_{\mathrm{P}}$ will be zero. In this case one can conclude that parents are fully altruistic, i.e. they value their children's leisure infinitely more than their own. The model also includes household plus parents' characteristics $\mathrm{X}_{\mathrm{H}}$. Note that, similarly to model (1), model (2) also controls for children's average age Age $\mathrm{C}_{\mathrm{CH}}$, and average children's observed characteristics $\mathrm{X}_{\mathrm{CH} \cdot}{ }^{32}$

Obviously, the OLS estimate of equation (1) is unlikely to deliver a consistent estimate of the parameter of interest $\phi_{\mathrm{P}}$. On the one hand, as I speculated above, some household unobserved characteristics (such as, for example, household income, parents' earnings, or the state of the local labor market) are likely to affect similarly the participation of each individual in the household, generating a source of upward bias in the OLS estimate. In addition, other variables (such as unobserved components of parents' and children's wages or possibly the state of the local technology) are likely to have opposite effect on parents' and children's participation, generating a downward bias in the OLS estimate. It follows that the OLS estimate of $\phi_{\mathrm{P}}$ is likely to be severely biased, although the direction of the bias is a priori unknown.

A simple inspection of equation (1), though, shows that one can use child labor laws to identify $\phi_{\mathrm{P}}$. To see this, observe that from equation (1) and aggregating across children within a household, it follows:

$$
\mathrm{d}_{\mathrm{CH}}=\beta_{0 \mathrm{C}}+\mathrm{Z}_{\mathrm{CH}} \beta_{2 \mathrm{C}}+\left(\beta_{1 \mathrm{C}}+\beta_{4 \mathrm{C}}\right) \mathrm{Age}_{\mathrm{CH}}+\mathrm{X}_{\mathrm{CH}}{ }^{\prime}\left(\beta_{3 \mathrm{C}}+\beta_{5 \mathrm{C}}\right)+\mathrm{X}_{\mathrm{H}}{ }^{\prime} \beta_{6 \mathrm{C}}+\delta_{\mathrm{CS}}+\mathrm{u}_{\mathrm{CH}}
$$

where $\mathrm{Z}_{\mathrm{CH}}$ is the average value of $\mathrm{Z}_{\mathrm{CiH}}$ across children in the household, i.e. the average difference between the age of children at or above legal working age in the household and the maximum age at

\footnotetext{
32 Others have estimated the effect of changes in one individual's labor supply on other household members' decision to work. Typically, these analyses refer to the effect of the husband's unemployment on his spouse's labor supply decision, an effect known as 'added worker effect' (Lundberg, 1985; Cullen and Gruber 2000; Stephens, 2002). The assumption that the household utility function is separable in the leisure of different individuals is used implicitly or explicitly in most of the literature of the 'added worker effect' (see, for example, Stephens, 2002).
} 
which children are prevented from working in their State of residence $\left(\mathrm{Z}_{\mathrm{CH}}=\Sigma_{\mathrm{i}} \mathrm{Z}_{\mathrm{CiH}} / \mathrm{N}_{\mathrm{CH}}\right)$. So aggregate labor supply among children in the household depends on the average age of the children in the household $\mathrm{Age}_{\mathrm{CH}}$, the average effect of child labor laws $\mathrm{Z}_{\mathrm{CH}}$, State dummies $\delta_{\mathrm{CS}}$ plus additional children's, household and parents' controls $\mathrm{X}_{\mathrm{CH}}$ and $\mathrm{X}_{\mathrm{H}}$.

A comparison of equations (2) and (3) suggests that the $Z_{C H}$ is a good instrument in order to identify the effect of children's labor supply on parents' work. Effectively, one can exploit changes in children's work eligibility to uncover the effect of child labor on parents' labor supply. If child labor laws generate some variation in parents' labor supply only through their effect on children's work, these candidate as ideal instruments for $\mathrm{d}_{\mathrm{CH}}$ in equation (3).

The way I identify $\phi_{P}$ consists in comparing two parents who are observationally equivalent (e.g., among other things, living in the same State, of the same age, the same gender, with the same number of children, with children of the same average age) except for the average age of the children who are legally allowed to work in their respective households. I attribute any difference in the labor market behavior of these two parents to the difference in their children's average work. Note that in the parents' equation (2) I explicitly control for the average age of the children in the household Age ${ }_{\mathrm{CH}}$, as well as for average children's observed characteristics $\mathrm{X}_{\mathrm{CH}}$. Effectively, I do not exploit the variation in Age $_{\mathrm{CH}}\left(\right.$ or $\left.\mathrm{X}_{\mathrm{CH}}\right)$ to identify the effect of changes in child labor on parents' labor supply. One advantage of this strategy is that parental labor market behavior might change as children age (or as other observed children's characteristics change) for reasons that have nothing to do with child labor. For example, parents might work more as their children grow older because necessary consumption increases or mothers do not need to stay at home and take care of their young children any more. 
An example can help clarify the identification strategy. Consider two fathers, say Andrew and Bob, both aged 40 and both living in Massachusetts where legal working age is equal to 14 . Assume they both have two children. Andrew has a child aged 13 and a child aged 15 . Bob has a child aged 12 and a child aged 16. The average age of children in the two households is the same and equals 14 . Assuming that child work grows with age after legal working age, average children's labor supply in Bob's household is potentially larger than in Andrew's because Bob's elder child is older than Andrew's and they can both work, so probably Bob's elder child will work more than Andrew's. However, neither Andrew's nor Bob's younger children are allowed to work. If there is a negative effect of children's work on parents' work one would expect Bob to work less than Andrew. Hence, I attribute the difference in the fathers' behavior to the effect of their children's work. It is important to note that I would not expect this effect to show up in the absence of child labor laws. If, in the absence of child labor laws, child labor force participation grows linearly with age (an assumption that I maintain throughout this paper), I would expect Bob's and Andrew's labor supply to be the same, since, while Bob's elder child would still work more than Andrew's elder child, Bob's younger child should work less than Andrew's younger child and the two effects should cancel out.

Effectively, identification stems from the discontinuity in the children's age participation profiles that (I argue) is induced by child labor laws. Crucial to the identification is the assumption that, in the absence of child labor laws, parents' participation is a linear function of children's average age, at least over the range of variation of the children's age variable (10-16). Note that, since the model is over-identified, one can easily test for the internal consistency of the instruments using an overidentification test. Effectively, the over-identification test in this setting boils down to asking whether the differential effect of child labor laws on average children's labor force participation across different States is the same as the differential effect on their parents' labor supply. If one cannot reject this 
hypothesis this might be taken as a suggestion that unobserved components of parents' labor supply are uncorrelated to the effect of child labor laws on parents' participation.

One difficulty with drawing any firm conclusion from the analysis above is that parents might not adjust their labor supply to changes in children's labor force participation for reasons other than their altruism towards children. For example, working children might withhold control over their labor income. In this case a zero value for $\phi_{\mathrm{P}}$ would say nothing about parents' preferences. This would instead suggest that children do not pool their resources with the rest of the household and they privately benefit from the returns from their own labor. ${ }^{33}$ One way to further investigate this issue consists in asking whether other children in the household benefit from child labor. If it is not only working children who benefit from the returns from their labor but also their siblings, this probably suggest that working children do not withhold complete control of their earnings. If it is the children (whether working or not) who benefit from child labor this might suggest that it is parents who redistribute the resources from child labor among the children in the household and this might be taken as an indication of parental altruism. In sum, one can examine whether anybody at all in the household benefits from increased child labor force participation. If nobody does, this probably suggests that working children withhold control over their earnings. If one finds that parents do but children do not, this suggests that parents privately benefit from child labor and possibly exploitation is at the root of child labor. If the opposite happens, this suggests that parents redistribute entirely the returns from child labor to the other children and hence that they are fully altruistic. Obviously, one might find than

\footnotetext{
${ }^{33}$ One could generate such a result in a model à la Chiappori (1992) where household members do not pool resources.
} 
both parents and children benefit, in which case one would conclude that parents are only partly altruistic and that exploitation is in part at the root of child labor. ${ }^{34} 35$

In order to investigate this issue formally, in the following I present a slightly modified version of equation (1) where I include as an additional regressor the proportion of working children in the household. In practice I estimate an equation like:

$$
\mathrm{d}_{\mathrm{CiH}}=\beta_{0 \mathrm{C}}+\phi_{\mathrm{C}} \mathrm{d}_{\mathrm{CH}}+\beta_{1 \mathrm{C}} \mathrm{Age}_{\mathrm{CiH}}+\mathrm{Z}_{\mathrm{CiH}}{ }^{\prime} \beta_{2 \mathrm{C}}+\mathrm{X}_{\mathrm{CiH}}{ }^{\prime} \beta_{3 \mathrm{C}}+\beta_{4 \mathrm{C}} \mathrm{Age}_{\mathrm{CH}}+\mathrm{X}_{\mathrm{CH}}{ }^{\prime} \beta_{\mathrm{C}}+\mathrm{X}_{\mathrm{H}}{ }^{\prime} \beta_{6 \mathrm{C}}+\delta_{\mathrm{CS}}+\mathrm{u}_{\mathrm{CiH}}
$$

Model (4) postulates that, everything else being equal, a rise in the proportion of working children in the household (including the child whose labor supply is measured on the left hand side) has an effect on each individual child's labor supply. ${ }^{36}$ Effectively, this is an externality that stems from the income effect of a rise in child labor (again under the assumption that the household utility function is separable in the leisure of different individuals). Again I derive this model in the Appendix. If $\phi_{C}$ is negative, this suggests that - conditional on $\mathrm{Z}_{\mathrm{CiH}}$ (plus the other controls) - a child in a household with a higher proportion of working children is less likely to work. One can take this as evidence that parents redistribute resources to the children in the household. ${ }^{37}$

\footnotetext{
${ }^{34}$ Note that no constraint holds on the relative value of parents' and children's relative weight in the household utility function (in terms of the theoretical model in the Appendix, these are $\alpha_{C}$ and $\alpha_{P}, P=F, M$ ). All these values might be zero if parents care infinitely more about consumption than about any household member's leisure or they might all be positive.

35 An additional reason why one might find no effect of children's work on parents' labor supply is that changes in children's work induced by child labor laws are largely expected. In the absence of credit constraints, a dynamic model of labor supply would predict no change in parents' labor supply as children turn legal working age. This point is often made in the 'added worker effect' literature. Again, though, if one finds some behavioral response among children (i.e. a negative externality), this suggests that the household is effectively unable to smooth completely income shocks, i.e. it is credit constrained. In this case, if parents are not fully altruistic, one would still expect to see some change in their labor supply as their children start to work.

${ }^{36}$ Obviously, children with no siblings do not contribute to the identification of $\phi_{\mathrm{C}}$ but they still contribute to the identification of the other coefficients in the regressions. See below for results on one-child households.

${ }^{37}$ Obviously, the coefficient $\phi_{\mathrm{C}}$ has to be interpreted as the effect of the externality net of any effect of child labor on parents' labor supply.
} 
Again note that the OLS estimate of $\phi_{\mathrm{C}}$ is likely to be inconsistent. In addition to the sources of bias affecting the OLS estimate of $\phi_{\mathrm{P}}$ in equation (2), in (4) the labor force participation of child $\mathrm{i}$ appears both on the left hand side and on the right hand side (in the term $d_{\mathrm{CH}}$ ) generating a classical division bias and leading to an upward bias in the OLS estimate of $\phi_{\mathrm{C}}$.

Again, however, one can try to identify consistently the effect of $\phi_{C}$ using equation (3) as a first stage equation. One can easily check that equation (3) still holds true although now the coefficient on each variable has to be rescaled by a factor $1 /\left(1-\phi_{\mathrm{C}}\right)$. If conditional on $\mathrm{Z}_{\mathrm{CiH}}, \mathrm{Z}_{\mathrm{CH}}$ can be legitimately excluded from equation (4), then one can use this as an instrument for $\mathrm{d}_{\mathrm{CH}}$ in each individual child's labor supply equation. ${ }^{38}$

Identification of the externality here is in the spirit of the discontinuous design approach that has been outlined above for parents. For example, I compare two children, say Alex and Ben, both aged 14 and both living in Massachusetts where legal working age is equal to 14. Both Alex and Ben are therefore legally allowed to work. Assume they both have two siblings. Alex has a sibling aged 13 and a sibling aged 15. Ben has a sibling aged 12 and a sibling aged 16. As above, the average age of children in the two households is the same and is equals 14 and, as above, average children's labor supply in Ben's household is larger than in Alex's because Ben's elder sibling is older than Alex's and Ben and Alex are of the same age. If there is some externality at work one would expect Ben to work less than Alex. One would also expect, that conditional on their age, Ben's siblings are less likely to work than Alex's. I attribute the difference in their behavior to the externality I am after. Again, for this

\footnotetext{
${ }^{38}$ Manski (1993) concludes perhaps a bit pessimistically that endogenous social effects cannot be identified. His argument is effectively that it is hard to legitimately exclude aggregate variables (such as $Z_{\mathrm{CH}}$ ) from the individual equation (4). I claim that in this setting the assumption that $\mathrm{Z}_{\mathrm{CH}}$ can be legitimately excluded from equation (4) is probably tenable. Also, as I argue in the text, this is testable since the model is over-identified.
} 
identification to hold, it must be the case that, in the absence of child labor laws, each child's labor force participation is a linear function of the average age of the children in the household. ${ }^{39}$

In the next section I present the regression results based on the empirical strategy I have just outlined.

\section{$\underline{\text { 3. Regression results }}$}

\section{$\underline{3.1 \text { The effect of child labor laws on children's labor supply }}$}

As a first step, in this section I investigate formally the effect of child labor laws on the probability of work of each individual child using equation (1). Essentially, I fine-tune the analysis in Section 1.3 using simple regression tools. Ignoring any additional controls, the model suggests that, in the absence of child labor laws, child labor should increase linearly with age (at the same rate across States).

In the first row of Table 4 I report the effect of child labor laws on total child labor supply (whether in the market or on the household farm) in each group of States. I include only controls for age Age $_{\mathrm{CiH}}$, State fixed effects $\delta_{\mathrm{CS}}$, and child labor laws $\mathrm{Z}_{\mathrm{CiH}}$, the effect of which I allow to vary by legal working age $(0,7,8,12,13,14,15)$. Standard errors in this and the following regressions are clustered by child's age and State. Overall this gives 336 cells ( 7 ages times 48 States). Consistent with my discussion in Section 1 and with the evidence in Figure 1, the model suggests that children's labor force participation increases with age as children turn legal working age and that the rate of growth is higher the higher the minimum working age. For example, the acceleration in participation after

\footnotetext{
${ }^{39}$ Note that the exclusion restriction here is particularly stringent since it requires $Z_{\mathrm{CH}}$ to be orthogonal to both $\mathrm{u}_{\mathrm{CiH}}$ and $\mathrm{u}_{\mathrm{PH}}$. As one can check from the Appendix, such error terms depend also on the unobserved components of wages for both the individual in question and other household members. A sufficient condition for the exclusion restriction to hold is that $Z_{\mathrm{CiH}}$ is strongly exogenous to the error term in the participation equation (i.e. exogenous to the unobserved component of labor force participation of everybody in the household).
} 
children turn legal working age in States with minimum working age 12 is about 4 percentage points a year. The acceleration is about twice as much for those living in States with minimum working age 14.

In row 2 I include some additional regressors. As said, the error term in equation (1) accounts for household unearned income, unobserved components of children's and parents' wages plus other determinants of labor force participation, including unobserved components of preferences and labor market and optimization errors. In the absence of direct measures of these variables, I approximate them with a set of observed controls. As children controls $\mathrm{X}_{\mathrm{CiH}} \mathrm{I}$ include a gender dummy and a linear term for the child's order of birth. I also include the average age of children aged 10-16 Age $\mathrm{C}_{\mathrm{CH}}$, and the average characteristics of children in the household $\mathrm{X}_{\mathrm{CH}}$. These include dummies for number of children 10-16 (from 1 to 6 or more) and the proportion of male children aged 10-16. As household and parents' controls $X_{H}$ I include the number of children aged 0-9, the proportion of children aged 0-9 in each one-year group, one urban dummy, a dummy for whether the household lives on a farm, three dummies for home ownership (owned and not mortgaged, mortgaged, rented), two dummies equal to one if the father or the mother are immigrants, three dummies for parents' race (white, black and other), two dummies equal to one if the father or the mother are illiterate, father's and mother's age and age squared. The point of this exercise is to test whether child labor laws are correlated with omitted household and children's characteristics. A comparison of the first and second rows in Table 4 shows virtually no difference in the estimates of the effect of child labor laws, implying little correlation between observed characteristics and child labor laws. ${ }^{40}$

\footnotetext{
${ }^{40}$ An analysis of the other coefficients provides some interesting insight into the factors that are correlated with child labor. First, boys are more likely to work than girls, a fact that was already noted in Table 1 and that remains true even once one conditions on other covariates. Second, younger children in the household tend to work less. Perhaps not surprisingly, child labor seems to be associated with poverty. Although no information on family income or assets is available in the 1920 Census, children living in rented or mortgaged homes tend to work more relative to those living in owned homes. This might reflect both an income effect and the effect of credit constraints on child labor (Fitzsimons, 2002; Dehejia and LlerasMuney, 2003). Note also that black kids tend to work substantially more than whites and those of other races. Children
} 
As an additional test for my model, in row 3 of Table 4 I have estimated the same equation as in rows 1 and 2 with the inclusion of household fixed effects. Household fixed effects absorb any heterogeneity across households that affects equally the labor force participation of children in the household. Identification here stems from variation in participation within households: essentially I compare children in the same household who are above or below legal working age. I still control for individual children's characteristics, namely age, sex and order of birth. It is remarkable how the effect of child labor laws remains essentially unchanged with respect to row 2 , suggesting that child labor laws are largely uncorrelated with household unobserved characteristics.

In the remaining part of Table 4 I report the effect of child labor laws on other measures of children's labor supply. Since child labor laws explicitly refer to the possession of a work permit, I would expect these laws only to have an effect on market work but not on work on the household farm. In rows 4 and 5 I therefore report separate estimates for the effect of child labor laws on market work and work on the household farm using the same set of controls as in row 2. The sum of market work and work on the household farm is total work, which is reported in row 2. As expected, one can observe that most of the variation in child labor induced by child labor laws comes from changes in market work. I find little or no systematic effect on work on the household farm. ${ }^{41}$

I finally report the estimate of the effect of child labor laws on children's schooling. Recall that the information on school enrollment comes from a question which is different from the one used to

living on farms are more likely to be engaged in work, a reflection of the fact that they can exploit the production possibilities on the family farm. Children in urban areas are also more likely to work, possibly a consequence of differences in child labor demand between cities and the countryside. Among the significant determinants of child labor is parents' education: both father's and mother's literacy status significantly lowers the probability of child work. Although this is not necessarily to be interpreted as a causal association, note finally that children in larger households tend to work more. The effect, however, seems to be non-linear as it tends to decline at larger parities.

${ }^{41}$ Most of the other variables in the model have similar effects on market work and work in the household enterprise. One clear exception is given by the status of living on a farm which obviously raises work on the household farm and depresses work in the market. 
ascertain gainful employment and that some children might work while being in school while others might be neither at work nor at school. It is interesting to note that child labor laws seem to have a very pronounced negative effect on school enrollment. One objection to this conclusion is that child labor laws might be correlated with compulsory schooling laws. In this case, I might be attributing to child labor laws the effect of the latter. I will go back to this issue later on in the paper where I will show that my results are insensitive to explicit controls for compulsory schooling laws.

As a following step, I turn to the effect of child labor laws on the proportion of working children by household, equation (3). This is a household version of the equation estimated in Table 4. Results are reported in Table 5. This can be interpreted as my first stage estimate for the parents' and children's labor supply equations estimated in the following section. I regress average child labor market participation in the household $\mathrm{d}_{\mathrm{CH}}$ on the average age of the children in the household Age $\mathrm{CH}_{\text {, }}$ State fixed effects $\delta_{\mathrm{CS}}$, and the average effect of child labor laws $\mathrm{Z}_{\mathrm{CH}}$, whose effect again I allow to vary by legal working age. ${ }^{42}$ This last set of variables will serve as instrumental variables for children's work in the following section. I experiment with and without additional controls. Note that because of the findings in Table 4 that child labor laws had no effect on work on the farm, here I only restrict to market work. In the first row I report the results of a regression with no additional controls. This is equivalent to the individual level specification with no controls in row 1 of Table 4 . In row 2 of Table 5 I control for the whole set of aggregate controls $\left(\mathrm{X}_{\mathrm{CH}}\right.$ and $\left.\mathrm{X}_{\mathrm{H}}\right)$. The results are remarkably consistent with the individual level model in Table 4, irrespective of whether or not I control for the whole set of controls. I find again a strong effect of child labor laws on the probability of child work at the

\footnotetext{
${ }^{42}$ This is a household-level GLS regression where each household is weighted by the number of children. In practice I have regressed the labor force of each individual child on the average value of child labor laws by household (plus the other covariates), imposing the same variance covariance structure of the error term (clustered by child's age and time) as in the individual level model (4).
} 
household level. I also find that the inclusion of household characteristics makes virtually no difference to the estimated coefficients, suggesting little correlation between child labor laws and observed household characteristics. It is worth noticing that the estimated effect of child labor laws on the average participation of the children in the household are somewhat below the individual level estimates in Table 4. This is a first indication that some externality might be at work, since the rise in average child labor force participation at the household level as children turn legal working age is lower than that implied by the sum of the individual effects (see equations (3) and (4)). In the last column of the Table, I report an F-test for the joint validity of the instruments. The data show that the instruments are jointly highly significant with an F-test of about 35 (p-value 0.000 ).

Having ascertained that child labor laws had a significant impact on the participation of children in the labor market and that they were largely uncorrelated with other determinants of child labor (including unobserved household characteristics that affect every child equally), I now turn to the effect of child labor on the labor supply of parents.

\subsection{The effect of child labor on household labor supply}

I now estimate equation (2) where I regress parents' participation $d_{\mathrm{PH}}$ on the proportion of working children in the household $\mathrm{d}_{\mathrm{CH}}$. As in the specification in Table 5, row 2, the model includes children's average age $\mathrm{Age}_{\mathrm{CH}}$, the full set of controls for aggregate children's characteristics $\mathrm{X}_{\mathrm{CH}}$, household and parents' characteristics $\mathrm{X}_{\mathrm{H}}$ and State fixed effects $\delta_{\mathrm{PS}}$.

Again, I use as a measure of children's labor supply $\mathrm{d}_{\mathrm{CH}}$ the proportion of children working in the market. The coefficient on this variable $\phi_{\mathrm{P}}$, which is reported in the Table, picks up the effect of child labor on parents' labor supply which I interpret as a measure of parental altruism. 
Regression results for fathers are reported in the first two columns of Table 6 . The first column reports OLS estimates and the second column the 2SLS estimates. The top part of the Table refers to the effect on total work while the bottom part refers to the effect on idleness.

I find a very small, positive and significant correlation between fathers' and children's labor. The estimated coefficient is 0.008 (s.e. 0.004 ) implying that a 50 percentage point rise in average child market work (equivalent to one extra child working in a household with two children aged 10-16) increases the probability of father's work by approximately 0.4 percentage points. However, this is not necessarily an indication of a behavioral response since unobserved determinants of parents' wages, household income and preferences might induce a bias in the OLS estimate of $\phi_{\mathrm{P}}$. In the second column I therefore report the 2SLS estimate of $\phi_{P}$, where I use the regression in Table 5, row 2 (i.e. the one with the whole set of household controls), in order to instrument for child market work at the household level. Although the 2SLS estimate cannot be told apart from the OLS estimate, once I instrument child labor by the effect of child labor laws I find a small and insignificant effect of children's market work on the father's labor supply (coefficient 0.004 , s.e. 0.022). Results for mothers are reported in the third and fourth column of Table 6. The correlation between children's and mother's labor supply is positive and significant, possibly a suggestion that mothers' and children's work are affected by similar forces. The estimated coefficient is 0.113 (s.e. 0.016 ) implying that a 50 percentage point rise in average child market work increases the probability of mother's work by approximately 5.5 percentage points. However, when child labor is instrumented with child labor laws, this correlation disappears. The coefficient is small (-0.015) and not significantly different from zero (s.e. 0.049). The overidentification test passes easily for fathers but fails marginally for mothers, suggesting that the instruments might be correlated with mother's labor supply and there are potential benefits from 
relaxing the restrictive specification in (2). I will investigate this issue below. ${ }^{43}$ Not surprisingly, the bottom part of the Table shows no effect of children's work on either the mother's or the father's inactivity rates. Taking together the evidence so far presented, it appears that the data are consistent with a model where the returns from child labor do not accrue to parents.

As a second step, I now turn to the effect of changes in children's average labor market opportunities on the labor supply of each individual child in the household. In the last two columns of Table 6 I report OLS and 2SLS estimates of the parameter $\phi_{C}$ in equation (4). I look at the effect of changes in average children's labor market participation $\mathrm{d}_{\mathrm{CH}}$ (including the participation of the child whose labor supply is measured on the left hand side) on each individual child's work, idleness and schooling. In row $1 \mathrm{I}$ report the results of a regression of child labor on a linear term in age Age $\mathrm{CiH}_{\text {, }}$ child labor laws $\mathrm{Z}_{\mathrm{CiH}}$, State dummies $\delta_{\mathrm{CS}}$, and the average labor market participation of children in the household $\mathrm{d}_{\mathrm{CH}}$, as implied by equation (4). This regression and all the other regressions in the last two columns of the Table include additional controls for children's individual characteristics $\mathrm{X}_{\mathrm{CiH}}$, aggregate children's characteristics Age $\mathrm{CH}_{\mathrm{H}}$ and $\mathrm{X}_{\mathrm{CH}}$, plus household and parents' characteristics $\mathrm{X}_{\mathrm{H}}$. Effectively, the equation estimated in row 1 is identical to the equation estimated in row 2 of Table 4 with the addition of the externality term. The OLS estimate shows a high, positive and significant correlation between average child labor market participation and the probability of individual child labor. The estimated coefficient on $\mathrm{d}_{\mathrm{CH}}$ is 0.919 (s.e. 0.041) implying that a 50 percentage point rise in

\footnotetext{
${ }^{43}$ I find that fathers in urban areas are significantly more likely to work and so are fathers who live on farms. Black and white fathers are more likely to work than those of other races, although immigrants are more likely to work than natives. Similarly to what one finds for kids, participation is higher the lower the family assets (picked up by home ownership). Father's participation rises with age, but at a decreasing rate and peaks at around age 40. Similar patterns can be detected for mothers. However, mother's labor force participation falls with a rise in the number of small children, obviously a consequence of child rearing. Some variables seem to have opposite effects on mother's and fathers' labor supply suggesting a pattern of intrahousehold substitution. For example, non-white women tend to work more than white ones, women living in farms appear less likely to work and women's participation varies along the husband's life cycle following a U-shape with a minimum when the husband is aged around 36.
} 
average child market work increases the probability of work of each individual child in the household by approximately 46 percentage points.

However, as already pointed out, these estimates are likely to be biased by the omission of unobserved household and children's characteristics as well as by a division bias. In the last column I therefore report the 2 SLS estimate of $\phi_{\mathrm{C}}$, where I use again the regression in Table 5 , row 2 , in order to instrument for child market work at the household level. I find a coefficient on total child labor of -0.164 (s.e. 0.075 ) implying that a 50 percentage point rise in average child market work reduces the probability of work of each individual child in the household by approximately 8 percentage points. The data pass the over-identification test very easily, suggesting that, conditional on the child's eligibility for work, the average effect of child labor laws has no separate effect on individual labor force participation except for its effect on average children's participation in the household.

An examination of other children's outcomes in rows 2 and 3 of Table 6 shows that most of the fall in children's labor force participation is compensated for by a rise in schooling. In row 2 I report the same regression as in row 1, where now the dependent variable is school enrollment. Once child labor is instrumented, there is a strong, positive but not very precisely determined effect of average child labor market participation on individual schooling. The effect is essentially equal (with a minus in front) to the effect on total children's labor supply. As shown in row 3, I find a small effect on idleness which cannot be told apart from zero. The results suggest that work might prevent children from attending school.

Note that because a rise in average child labor force participation tends to decrease the probability of work of each individual child in the household, this suggests again that the data are unlikely to be severely affected by underreporting. If underreporting were to explain the variation in 
participation around legal working age one would not expect any behavioral effect of changes in participation induced by child labor laws. ${ }^{44}$

Taking together the evidence so far presented, it appears that parents redistribute entirely the returns from child labor to their children in the form of lower labor supply and higher schooling (plus possibly increased consumption).

I now turn to a number of checks on my data to prove the robustness of my results and investigate further the effect of child market work on household labor supply.

\section{$\underline{\text { 4. Sensitivity analysis }}$}

In this section I present a number of checks and extensions to the model estimated in the previous section. First, I saturate the model further by allowing for State-specific age participation profiles. Second, I examine more closely the effect of compulsory schooling laws. Third, I attempt to separately identify the effect of boys' and girls' market work on household labor supply, As a fourth check, I examine the effect of children's market work on the household's allocation of time between the market and home production. Finally I restrict to one-child households.

\footnotetext{
${ }^{44}$ As a check for this I have simulated a model where individual child labor does not depend on average child labor force participation in the household. I have used the regression coefficients from the individual level regression with controls (row 2 in Table 4) to simulate this model and I have appended a normal error term with the same variance as the residuals from my estimated equation. I have then constructed average child labor force participation by household and included this as an additional regressor which I have instrumented using child labor laws. The estimated coefficient is 0.013 (s.e. 0.045), suggesting that measurement error is not by itself able to induce the negative correlation I have found above.
} 


\section{$\underline{4.1 \text { State-specific age participation profiles }}$}

As a first check for the robustness of my results I saturate my econometric model further. In Section 3 I have discussed at some length the identification assumption underlying my estimates of the effect of child market work on household labor supply. I have emphasized how identification relies on discontinuous design. Effectively, I have assumed that, in the absence of child labor laws, each individual's participation is a linear function of the average age of the children. One additional assumption that I have maintained so far is that, in the absence of child labor laws, age participation profiles evolve similarly across different States.

There are reasons to believe, though, that this last assumption is not necessarily a good one. Suppose that child labor laws are endogenously set to accommodate the state of the local labor market. For example, suppose that minimum working age is lower the higher the demand for child labor (because of the pressure exercised by the owners of capital or if capital migrates where child labor is available). If children and parents are substitutes in the firm's production function (as in Basu and Van, 1998), one might find that parents of working children do not tend to work less simply because of this aggregate labor demand effect which tends to raise their employment. Because of this, one might erroneously conclude that there is no behavioral response of parents to changes in child labor. By the same token, suppose that minimum working age is lower the higher the supply of child labor (because of the pressure exercised by parents or the immigration of households with children). Then one might find that siblings of working children are more likely to attend school and less likely to work simply because of this aggregate labor supply effect, that tends to depress everybody's wages. In this case, one would find a negative externality among children that has nothing to do with the behavioral response of the household to the availability of additional resources. Obviously, since the model allows for children's and parents' State fixed effect, any aggregate shock that has a similar effect on every child or 
every parent in the economy, independent of his age, is completely controlled for. However, if such patterns of demand and supply affect differentially participation along the life cycle, then my estimates in Table 6 are likely to be biased. The direction of the bias is uncertain depending on whether one thinks that it is omitted labor supply or omitted labor demand which possibly drives the results, and depending on which household member (children or parents) one is examining.

One way to accommodate these concerns is to assume that participation age profiles for both children and parents are State-specific. The identification stemming from the discontinuity around legal working age induced by child labor laws is still warranted by the variation within States. One simple way to embody this into the model in (1) to (4) is to fully interact children's age and parents' age and age squared with State dummies. Obviously, this implies that one will have to control additionally for the differential effect of children's average age across States on the labor supply of each household member. I report the 2SLS results for this pretty unrestricted model in row 1 of Table 7 . I find no difference in my estimates with respect to the baseline case in Table 6 , although the estimates for children are somewhat less precise. Note also that the over-identification test now passes easily for mothers, suggesting that there are potential benefits from relaxing the model.

\section{$\underline{4.2 \text { Compulsory schooling laws }}$}

One second potential worry with the results in Tables 4 to 6 is that I am attributing to child labor laws the effect of other forces, in particular the effect of compulsory schooling laws. Although this is unlikely to affect my overall conclusions, there is a debate as to whether compulsory schooling laws are a more effective way of restraining child labor than child labor laws (Krueger, 1996), and my analysis could potentially shed some light on the relative effect of these two policies in 1920 America. 
As a first observation, note that, since I find little or no effect of child labor laws on work on the household farm, this might be a suggestion that what I am identifying is genuinely the effect of child labor laws rather than the effect of compulsory schooling laws. If compulsory schooling laws are enforced and this is the variation I am identifying out of, one would expect also participation on the household farm to vary with child labor laws, a fact that does not appear to be true.

As an additional check, I have replicated the estimates in Table 6 using only data on households living in States with a compulsory schooling age of 16 . As noted above, almost $90 \%$ of children in the sample are subject to a compulsory schooling age of 16. Results are reported in row 2 of Table 7 . One can easily see that, when this restricted sample is used, my results are essentially unchanged with respect to Table 6. I find no significant effect on parents' labor supply and a negative, although less precisely estimated, effect on children's labor supply. ${ }^{45}$ I conclude that omission of compulsory schooling laws is likely not to be problematic. ${ }^{46}$

\footnotetext{
${ }^{45}$ I have also replicated this exercise re-defining compulsory schooling age to account for continuation age. Estimates based on the sample of States with this broad definition of compulsory schooling age equal 16 give practically identical results to the ones in Table 7.

${ }^{46}$ This is also consistent with what others have found on the educational achievement of cohorts who were attending school over these years. Both Acemoglu and Angrist (2000) and Lleras-Muney (2002) shows that child labor laws were more effective in raising education than compulsory schooling laws. Margo and Finegan (1996), in their analysis of 1900 America, find that compulsory schooling laws had a strong and significant effect on school attendance when combined with child labor legislation.
} 


\subsection{Gender differences in child labor}

So far I have treated the labor supply of boys and girls similarly. Implicit in my model (1) to (4) is the hypothesis that the effect of child labor laws is the same across gender groups and that the effect of a rise in child labor on household labor supply is the same whether this comes from changes in boys' or girls' participation. In this section I investigate whether departures from this fairly restrictive specification make any difference to my results. In particular, I am interested in assessing whether there are systematically different responses of boys and girls to child labor laws and whether changes in boys' and girls' work have any differential effect on household labor supply. Thomas (1994), using data for a variety of countries, for example, suggests that parents might have stronger preferences for children of the same gender, in which case one would expect fathers and mothers to react differently to changes in the labor supply of boys and girls. In order to test for this, for each household I have computed the number of boys and girls doing market work over the total number of children and I have regressed these two variables in turn on the sum of the ages of boys and girls at or above legal working age minus the maximum age at which is prohibited, divided by the number of children (equation (3)). Regressions include, in addition to the whole set of controls as above, controls for the sum of the ages of boys and girls over the total number of children, and the number of boys and girls in the household. I have used the results from these two regressions in order to instrument boys' and girls' market work in a set of regressions where the dependent variable is individual total work (equations (2) and (4)). Now I allow the coefficient on girls' and boys' market work to vary. Regressions for children include the same controls as in Table 6, plus the interaction of the child's age with a gender dummy and the interaction of child labor laws with a gender dummy. In row 3a of Table 7 I report the effect of boys' market work on total labor supply of different household members, while in row $3 b$ I report the results for girls' market work. It seems that there is no differential effect of boys' and girls' labor market work 
on fathers' labor supply. As for mothers, they seem to cut their labor supply as boys work while the same does not occur when girls work, suggesting perhaps that mothers are biased in favor of girls. Standard errors, though, are high and one cannot reject the hypothesis that mothers do not react to either boys' or girls' increased labor supply. As for children (whether boys or girls), I find no evidence of a differential effect coming from boys' or girl's work and the point estimates are similar to the ones in Table 6. Overall, these results suggest that the potential bias that comes from imposing the fairly restrictive specification of Section 3 (where girls and boys react similarly to child labor laws and have similar effects on other household members' labor supply) is likely not to be severe.

\subsection{The allocation of time between the market and the farm}

In Table 6 I have examined the effect of child market work on household total work. I now turn to estimating separately the effect of this variable on market work and work on the household farm. A rise in labor market participation of children might have different effects on these two outcomes according to the technology of home production (and maintaining the assumption that the household utility function is separable in different individual members' labor supply). If different household members are complements in home production, then a rise in the wage of one child might decrease labor force participation of other household members via a fall in their work on the household farm. This happens if, as a child turns legal working age, he switches from working on the household farm to working in the market. The opposite will happen if different household members are substitutes. ${ }^{47}$ In Table 7, row 4, I examine the effect of a rise in average children's labor market participation on each individual's work in the market, while in row 5 I report results for work on the household farm. I find that as

\footnotetext{
${ }^{47}$ This is the argument made by Gronau (1973) in the context of the labor supply choices of two individuals (wife and husband) who can allocate their time between the market, home production and leisure.
} 
children move to the market, fathers tend to move to the market too, suggesting if anything a pattern of complementarity. Coefficients, however, cannot be told apart from zero and one cannot reject the hypothesis that the effect on market work and farm work of fathers and mothers are both equal to zero. As for children, the effect on both market and non-market work is negative but only significant for nonmarket work. The point estimate in both cases is -0.08 , implying that a 50 percentage point rise in average children's market work reduces each individual child's participation in the market and in home production by about 4 percentage points. The data pass the over-identification test quite easily. Overall, I find little differential effect of children's market work on the household's allocation of time between the market and the farm.

\subsection{One child households}

As a last check, I estimate a household labor supply equation for households with only one child aged 10 to 16 . Obviously, in this case, I do not investigate the effect of the externality on children's labor supply. I simply regress parents' work on a dummy for child's work instrumented by child labor laws. This is very similar to the classical approach to the 'added worker effect' (Lundberg, 1985; Cullen and Gruber 2000; Stephens, 2002), where one individual's labor supply (generally the wife's) is regressed on another individual's employment status (generally the husband's), plus the individual's wage. The results are reported in the last row of Table 7. Again, I find no significant effect of child labor on parents' work.

\section{$\underline{\text { 5. Conclusions }}$}

In this paper I have examined the effect of a rise in the market work of children aged 10 to 16 on the labor supply decisions of different household members in 1920 America. In order to identify the 
exogenous effect of a rise in child labor, I have used the discontinuity in children's age participation profiles around minimum working age induced by child labor laws.

First, my empirical estimates show a strong and discernible impact of child labor laws on children's labor market participation in 1920 America. I find evidence that children below working age do not perform any work and that participation grows rapidly with age as children turn legal working age. Consistent with the expected effect of child labor laws, I only find an effect of legislation on children's work in the market but no effect on children's work on the household farm. I also present some evidence showing that the effect of child labor laws on children's labor force participation is unlikely to be due to underreporting, i.e. to the fact that child labor is not reported by parents where banned.

Second, I find that most of the returns from child labor are redistributed to children in the household in terms of lower labor supply and higher school attendance. A 50 percentage point rise in the proportion of children working in the market (equal to one extra child working out of two) produces - everything else equal - a fall in the participation of each individual child of around 8 percentage points and a similar rise in each individual child's schooling. My results, though, show no effect of increased resources coming from child labor on either the father's or the mother's labor supply.

Since child labor laws differ across States and have different effects on children's labor force participation according to their level, effectively the model is over-identified. In support of the identification strategy used in the paper, the over-identification test leads to the conclusion that the instruments are mutually consistent.

Later in the paper I present a number of robustness checks. First, I show that my results are essentially unchanged if I saturate the model further, allowing for State-specific age participation profiles. This extension of the model has the advantage of controlling for the fact that different child 
labor laws are potentially endogenously set across States in order to accommodate different levels of child labor supply and demand. I then show that differences in schooling laws across States cannot be held responsible for the effect detected in the paper, suggesting that child labor laws have an independent effect on children's labor supply and schooling. As an additional result, I find little evidence of a differential effect of boys' and girls' work on household labor supply and I find no statistically significant differential effect of changes in children's market work on the household allocation of time between market and non-market work, although results are somewhat imprecise and need to be taken with some caution. As a last check, I estimate the effect of a rise in child labor on parents' labor supply in one-child households. Again the results confirm my previous findings.

A simple dictatorial model of household labor supply underlying my analysis is presented in the Appendix. The model suggests that, if it is parents who take decisions about their own and their children's labor supply, one can look at different household members' labor supply responses to exogenous changes in average children's labor force participation in order to infer the degree of parental altruism. The model makes the - perhaps obvious - point that, even if parents are fully altruistic, one would not expect working children to privately benefit from their earnings. Parental altruism towards their children implies that parents will redistribute the additional resources available to the household from child labor to all children, whether working or not.

I argue that my results are consistent with a model with full altruism on the part of parents. This is the model generally taken for granted in most of the theoretical literature on child labor and one that my empirical estimates lend strong support to. Although this does not rule out the possibility that child labor is inefficient and that policy interventions might be desirable (Baland and Robinson, 2000), my results suggest that it is not parents' greediness which explains why children work and do not attend school. 


\section{$\underline{\text { References }}$}

Acemoglu Daron and Joshua Angrist (2000), 'How Large Are Human Capital Externalities?, Evidence from Compulsory Schooling Laws', NBER Macroannual 2000, 9-59.

Altonji Joseph, Fumio Hayashi and Laurence Kotlikoff (1997), 'Parental Altruism and Inter Vivos Transfers: Theory and Evidence', Journal of Political Economy, 105, 1997, 1121-66.

Angrist Joshua and Alan Kruger (1991), 'Does Compulsory School Attendance Affect Schooling and Earnings?’ Quarterly Journal of Economics, 106, 1991, 979-1014.

Ashenfelter Orley (1980), 'Unemployment as Disequilibrium in a Model of Aggregate Labor Supply', Econometrica, 48, 1980, 547-564.

Ashenfelter Orley and James Heckman (1974), 'The Estimation of Income and Substitution Effects in a Model of Family Labor Supply‘, Econometrica, 42, 1974, 73-86.

Baland Jean Marie and James Robinson (2000), 'Is Child Labor Inefficient?', Journal of Political Economy, 108, 2000, 633-679.

Basu Kaushik and Pham Hoang Van (1998), 'The Economics of Child Labor', American Economic Review, 89, 1998, 412-427.

Becker Gary (1981), A Treatise on the Family, Harvard University Press, 1981.

Boozer Michael, Alan Krueger and Shari Wolkon (1992), 'Race and School Quality since Brown v. Board of Education', Brookings Papers on Economic Activity: Microeconomics, 1992, 269-326.

Card David and Alan Krueger (1992), 'School Quality and Black-White Relative Earnings: A Direct Assessment', The Quarterly Journal of Economics, 107, 1992, 151-200.

Chiappori Pierre-Andre (1992), 'Collective Labor Supply and Welfare', Journal of Political Economy, $100,1992,437-467$.

Cullen Julie Berry and Jonathan Gruber (2000), 'Does Unemployment Insurance Crowd out Spousal Labor Supply?', Journal of Labor Economics, 18, 2000, 546-572.

Deaton Angus and John Muellbauer (1980), Economics and Consumer Behavior, Cambridge University Press, 1980.

Dehejia Rajeev and Adriana Lleras-Muney (2003), 'Why Does Financial Development Matter? The United States from 1900 to 1940‘, NBER Working Paper No 9551, 2003.

Fitzsimons Emla (2002), 'The Effects of Risk on Education and Child Labour', IFS Working Paper W02/07, (updated February 2003). 
Fuller Raymond (1922), 'Child labor and Federal Legislation', American Review of Reviews, 66, 1922.

Goldin Claudia (1996), 'Labor Markets in the Twentieth Century', in S.L. Engeman and R.E. Gallman (eds.), The Cambridge History of the United States, 1996.

Goldin Claudia (1998), 'America's Graduation from High School: The Evolution and Spread of Secondary Schooling in the Twentieth Century', Journal of Economic History, 58, 1998, 345374.

Goldin Claudia (1999a), 'A Brief History of Education in the United States', NBER Working Paper No. h0119, 1999.

Goldin Claudia (1999b), 'Egalitarianism and the Returns to Education during the Great Transformation of American Education', Journal of Political Economy, 107, 1999, S65-94.

Goldin Claudia and Kenneth Sokoloff (1982), 'Women, Children, and Industrialization in the Early Republic: Evidence from the Manufacturing Censuses', The Journal of Economic History, 42, 1982, 741-774.

Goldin Claudia and Lawrence Katz (1996), 'Technology, Skill, and the Wage Structure: Insights from the Past', American Economic Review, 86, 1996, 252-57.

Goldin Claudia and Lawrence Katz (1997), 'Why the United States Led in Education: Lessons from Secondary School Expansion, 1910 to 1940’, NBER Working Paper w6144, 1997.

Goldin Claudia and Lawrence Katz (1998), 'The Origins of Technology-Skill Complementarity', Quarterly Journal of Economics, 113, 1998, 683-732.

Goldin Claudia and Lawrence Katz (2000), 'Education and Income in the Early 20th Century: Evidence from the Prairies', Journal of Economic History, 60, 2000, 782-818.

Gronau Ruben (1973), 'The Intrafamily Allocation of Time: the Value of Housewives' Time', American Economic Review, 63, 1973, 634-651.

Krueger Alan (1996), 'Observations on International Labor Standards and Trade', in Bruno M. and B. Pleskovic (eds.), Annual World Bank Conference on Development Economics, 281-302, 1996.

Landes William and Lewis Solmon (1972), 'Compulsory Schooling Legislation: An Economic Analysis of Law and Social Change in the Nineteenth Century', The Journal of Economic History, 32, 1972, 54-91.

Lleras-Muney Adriana (2002), 'Were Compulsory Attendance and Child Labor Laws Effective?: An Analysis from 1915 to 1939', Journal of Law and Economics, 45, 2002, 401-35.

Lundberg Shelly (1985), 'The Added Worker Effect', Journal of Labor Economics, 3, 1985, 11-37. 
Manski Charles (1993), 'Identification of Endogenous Social Effects: The Reflection Problem', The Review of Economic Studies, 60, 1993, 531-542.

Margo Robert and Aldrich Finegan (1996), 'Compulsory Schooling Legislation and School Attendance in Turn-of-the-Century America: A "Natural Experiment" Approach', Economic Letters, 53, 1996, 103-110.

Moehling Carolyn (1999), 'State Child Labor Laws and the Decline in Child Labor', Explorations in Economic History, 36, 1999, 72-106.

Parson Donald and Claudia Goldin (1989) , 'Parental Altruism and Self-Interest: Child Labor Among late Nineteenth Century American Families’, Economic Inquiry, 27, 1989, 637-659.

Putnam Robert (2000), Bowling Alone: The Collapse and Revival of American Community, Simon \& Schuster, New York, 2000.

Sanderson Allen (1974), 'Child-Labor Legislation and the Labor Force Participation of Children', The Journal of Economic History (in Summaries of Doctoral Dissertations), 34, 1974, 297-299.

Stephens, Melvin (2002), 'Worker Displacement and the Added Worker Effect', Journal of Labor Economics, 20, 2002, 504-37.

Thomas Duncan (1990), 'Intra-Household Resource Allocation: An Inferential Approach', The Journal of Human Resources (in Symposium on Household Bargaining Models), 25, 1990, 635-664.

Thomas Duncan (1994), 'Like Father, like Son; Like Mother, like Daughter: Parental Resources and Child Height', The Journal of Human Resources, 29, (Special Issue: The Family and Intergenerational Relations), 1994, 950-988.

Trattner Walter (1970), Crusade for the children : a history of the National Child Labor Committee and child labor reform in America, Quadrangle Books, Chicago, 1970.

Willoughby William (1890), 'Child Labor', Publications of the American Economic Association, 5, 1890, 5-70. 


\section{Appendix: A stylized model of household labor supply with child labor}

In this Appendix I present a stylized model of household labor supply with child labor. ${ }^{48}$ I show how one can derive equations (1) to (4) from this model and how one can interpret the coefficients on children's work in these equations as a measure of parental altruism.

Consider a household $\mathrm{H}$ composed of $\mathrm{N}_{\mathrm{CH}}$ children (denoted by $\mathrm{C}_{\mathrm{i}}, \mathrm{i}=1, \ldots \mathrm{N}_{\mathrm{CH}}$ ), a father (denoted by F) and a mother (denoted by M). Suppose that each individual j's (either a child's or a parent's) utility depends on the consumption of two goods: some public good $\mathrm{E}_{\mathrm{H}}$, and own leisure (1$\mathrm{e}_{\mathrm{jH}}$ ), where $0<=\mathrm{e}_{\mathrm{jH}}<1$ denotes work, with 1 being the endowment. Assume that parents maximize some linear combination of their children's and their own individual utilities according to CRTS CobbDouglas with $\alpha_{C} / \mathrm{N}_{\mathrm{CH}}$ being the weight that parents attach to each child's leisure and $\alpha_{\mathrm{F}} / \mathrm{N}_{\mathrm{CH}}$ and $\alpha_{\mathrm{M}} / \mathrm{N}_{\mathrm{CH}}$ respectively the father's and mother's utility of work:

$$
\mathrm{U}_{\mathrm{H}}=\left[\left(\mathrm{N}_{\mathrm{CH}}-\alpha_{\mathrm{F}}-\alpha_{\mathrm{F}}-\mathrm{N}_{\mathrm{CH}} \alpha_{\mathrm{C}}\right) \ln \mathrm{E}_{\mathrm{H}}+\alpha_{\mathrm{F}} \ln \left(1-\mathrm{e}_{\mathrm{FH}}\right)+\alpha_{\mathrm{M}} \ln \left(1-\mathrm{e}_{\mathrm{MH}}\right)+\alpha_{\mathrm{C}} \Sigma_{\mathrm{i}} \ln \left(1-\mathrm{e}_{\mathrm{CiH}}\right)\right] / \mathrm{N}_{\mathrm{CH}}
$$

subject to the budget constraint:

$$
\mathrm{E}_{\mathrm{H}}=\Sigma_{\mathrm{i}} \mathrm{w}_{\mathrm{CiH}} \mathrm{e}_{\mathrm{CiH}}+\mathrm{w}_{\mathrm{FH}} \mathrm{e}_{\mathrm{FH}}+\mathrm{w}_{\mathrm{MH}} \mathrm{e}_{\mathrm{MH}}+\mathrm{Y}_{\mathrm{H}}
$$

and the time constraints. ${ }^{49} \mathrm{Y}_{\mathrm{H}}$ denotes household unearned income. In equilibrium:
(A1.1) $\mathrm{d}_{\mathrm{PH}}=\mathrm{I}\left(\mathrm{e}_{\mathrm{PH}}>0\right)=\mathrm{I}\left(\mathrm{w}_{\mathrm{PH}}>\alpha_{\mathrm{P}} \mathrm{E}_{\mathrm{CH}}{ }^{*} / \mathrm{A}_{\mathrm{H}}\right)$ $\mathrm{P}=\mathrm{F}, \mathrm{M}$
(A1.2) $\mathrm{d}_{\mathrm{CiH}}=\mathrm{I}\left(\mathrm{e}_{\mathrm{CiH}}>0\right)=\mathrm{I}\left(\mathrm{w}_{\mathrm{CiH}}>\alpha_{\mathrm{C}} \mathrm{E}_{\mathrm{CH}}^{*} / \mathrm{A}_{\mathrm{H}}\right)$
$\mathrm{i}=1, \ldots \mathrm{N}_{\mathrm{CH}}$

\footnotetext{
${ }^{48}$ In particular, the model is static and ignores any intertemporal substitution of labor. I discuss in footnote 35 how my conclusions are likely to be unaffected by dynamic considerations.

${ }^{49}$ The assumption that parents care equally for the well-being of each individual child is neutral. One can imagine that this is true conditional on some children's covariates. The Cobb-Douglas assumption is used only for convenience. One crucial hypothesis, though, is that the household utility function is additively separable in different individuals' leisure. This implies that a rise in one individual's wage has only an income effect on another individual's participation. If this assumption is violated, then the interpretation of the estimates in the text is affected.
} 
where:

$$
\begin{aligned}
& \mathrm{E}_{\mathrm{CH}}{ }^{*}=\left(\Sigma_{\mathrm{i}} \mathrm{w}_{\mathrm{CiH}} \mathrm{d}_{\mathrm{CiH}}+\mathrm{w}_{\mathrm{FH}} \mathrm{d}_{\mathrm{FH}}+\mathrm{w}_{\mathrm{MH}} \mathrm{d}_{\mathrm{MH}}+\mathrm{Y}_{\mathrm{H}}\right) / \mathrm{N}_{\mathrm{CH}} \\
& \mathrm{A}_{\mathrm{H}}=\left[\mathrm{N}_{\mathrm{CH}}-\alpha_{\mathrm{F}}\left(1-\mathrm{d}_{\mathrm{FH}}\right)-\alpha_{\mathrm{M}}\left(1-\mathrm{d}_{\mathrm{MH}}\right)-\alpha_{\mathrm{C}} \Sigma_{\mathrm{i}}\left(1-\mathrm{d}_{\mathrm{iH}}\right)\right] / \mathrm{N}_{\mathrm{CH}}
\end{aligned}
$$

and I( ) is an indicator function. Equations (A1.1) and (A1.2) make the obvious point that the probability that an individual $\mathrm{j}$ in household $\mathrm{H}$ participates in the labor market increases as his wage $\mathrm{W}_{\mathrm{jH}}$ rises and as household income (including the earnings accruing to the individual whose labor supply we are trying to explain) $\mathrm{E}_{\mathrm{CH}}{ }^{*}$ falls. The effect of a change in household income on an individual's labor force participation depends on $\alpha_{\mathrm{j}} / \mathrm{A}_{\mathrm{H}}$, i.e. the individual's disutility of work $\left(\alpha_{\mathrm{j}}\right)$ - as evaluated by parents - standardized to some function of the utility of consumption plus the utility of leisure of those household members who happen to work in equilibrium $\left(\mathrm{A}_{\mathrm{H}}\right)$. The model suggests that one can infer the weight that parents attach to each individual's well-being by analyzing how, conditional on the individual's wage, individual participation is affected by changes in household income. $^{50}$ Effectively, by analyzing which household member benefits - in terms of increased consumption of leisure - from the availability of additional monetary resources, one can try to draw some conclusions on parents' preferences for their children's and their own well-being and ultimately draw some inference on the degree of parental altruism. ${ }^{51}$

In order to make the model operational, note that each individual's labor force participation decision $d_{j H}$ depends on the individual's wage, some measure of the disutility of work $\alpha_{j} / A_{H}$, and perchild household income $\mathrm{E}_{\mathrm{CH}}{ }^{*}$. Since both $\alpha_{\mathrm{j}} / \mathrm{A}_{\mathrm{H}}$ and $\mathrm{E}_{\mathrm{CH}}{ }^{*}$ depend on the $\mathrm{d}_{\mathrm{jH}}$ 's, similarly to many others

\footnotetext{
${ }^{50}$ A problem with this model is that the finding that parents are fully altruistic, i.e. that they care infinitely more for their children's well-being than for their own, is not consistent with the fact that some mothers do not work. Perhaps a more realistic model would allow for mothers' work at home. However, since my data have no information on household chores, I ignore this possibility in the model.

${ }^{51}$ In this model, if children's earnings contribute to the purchase of some public consumption good, parents might still benefit from child labor despite them valuing their children's leisure infinitely more than their own.
} 
in the household labor supply literature (e.g. Ashenfelter and Heckman, 1974) I evaluate these terms at some arbitrary value of $d_{j H}$. Given that $d_{j H}$ is a $0 / 1$ variable, the obvious choice is $d_{j H}=1$. It is easy to see that in this case $\mathrm{A}_{\mathrm{H}}=1$, while per-child household income $\mathrm{E}_{\mathrm{CH}}{ }^{*}$ equals per-child household full income $\left(\Sigma_{\mathrm{i}} \mathrm{W}_{\mathrm{CiH}}+\mathrm{w}_{\mathrm{FH}}+\mathrm{w}_{\mathrm{MH}}+\mathrm{Y}_{\mathrm{H}}\right) / \mathrm{N}_{\mathrm{CH}}$. Using the above assumptions, I finally express each individual participation decision as a linear function of his own wage and average children's earnings $\mathrm{w}_{\mathrm{CH}}=\Sigma_{\mathrm{i}} \mathrm{w}_{\mathrm{CiH}} / \mathrm{N}_{\mathrm{CH}}$ :

(A2.1) $\mathrm{d}_{\mathrm{PH}}=\theta_{0 \mathrm{p}}+\theta_{1 \mathrm{PW}}+\theta_{2 \mathrm{PW}}+\mathrm{m}_{\mathrm{pH}}$

(A2.2) $\mathrm{d}_{\mathrm{CiH}}=\theta_{0 \mathrm{C}}+\theta_{1 \mathrm{C}} \mathrm{W}_{\mathrm{iH}}+\theta_{2 \mathrm{CW}} \mathrm{W}_{\mathrm{CH}}+\mathrm{m}_{\mathrm{iH}}$

$$
\mathrm{p}=\mathrm{F}, \mathrm{M}
$$$$
\mathrm{i}=1, . ., \mathrm{N}_{\mathrm{CH}}
$$

where the first equation refers to children, the second to parents and $\mathrm{m}$ is an error terms that accounts for optimization and labor market errors plus unobserved determinants of participation including perchild household unearned income and parents' earnings $\left(\left[\mathrm{Y}_{\mathrm{H}}+\mathrm{W}_{\mathrm{FH}}+\mathrm{w}_{\mathrm{MH}}\right] / \mathrm{N}_{\mathrm{CH}}\right)$. Model (A2) suggests that a regression of individual participation on the individual's wage and the average potential earnings of all children in the household should provide some indication about who in the household benefits from the additional resources available to the household from child labor. ${ }^{52}$ Consistent with (A1), one can interpret the coefficient on $\mathrm{w}_{\mathrm{CH}}$ as a measure of the parents' evaluation of each individual's wellbeing. If parents care for their children's well-being, children will benefit from the additional resources available to the household from child labor, and one would expect $\theta_{2 \mathrm{C}}$ to be negative, while if parents do not care about their children's well-being one would expect $\theta_{2 \mathrm{C}}$ to be zero. Similarly, a value of $\theta_{2 \mathrm{P}}$ equal to zero suggests that parents care relatively little for their own well-being. In the extreme case in

\footnotetext{
${ }^{52}$ Obviously, because of the way I have specified the model (a dictatorial or unitarian model of labor supply), changes in the income accruing to different household members need to have the same effect on each individual's labor supply. Perhaps a better model would allow for different income elasticities according to whom in the household the monetary resources accrue to (as, for example, in Thomas, 1990). Since I have no information on earnings other than the ones accruing to children (because of the effect of child labor laws), I remain agnostic on this point.
} 
which parents are fully altruistic $\left(\theta_{2 \mathrm{P}}=0\right)$, they will work irrespective of their children's wages and household income.

One difficulty with identifying the parameters in equation (A2) is that no direct information on market wages is available in the 1920 Census for either parents or children which obviously hinders the identification of the parameters of interest. To get round this problem, suppose that for each child in the household there exists a vector of $\mathrm{L}_{\mathrm{MAX}}$ variables $\mathrm{Z}_{\mathrm{CiHL}}\left(\mathrm{L}=1,2, . . \mathrm{L}_{\mathrm{MAX}}\right)$ that affect his market wage. I assume that children's wages are some linear function of such variables $Z_{\mathrm{CiHL}}$ :

(A3) $\quad \mathrm{w}_{\mathrm{CiH}}=\gamma_{0}+\mathrm{Z}_{\mathrm{CiH}} \gamma_{1}+\mathrm{f}_{\mathrm{CiH}}$ $\mathrm{i}=1, . ., \mathrm{N}_{\mathrm{CH}}$

where $\mathrm{Z}_{\mathrm{CiH}}$ is a vector of $\mathrm{L}_{\mathrm{MAX}}$ elements and $\mathrm{f}_{\mathrm{CiH}}$ is an error term accounting for unobserved components of market wages. By combining equations (A2) and (A3) this leads to:

(A4.1) $d_{\mathrm{PH}}=\beta_{0 \mathrm{P}}+\phi_{\mathrm{P}} \mathrm{d}_{\mathrm{CH}}+\mathrm{u}_{\mathrm{PH}}$ $\mathrm{P}=\mathrm{F}, \mathrm{M}$

(A4.2) $\mathrm{d}_{\mathrm{CiH}}=\beta_{0 \mathrm{C}}+\phi_{\mathrm{C}} \mathrm{d}_{\mathrm{CH}}+\mathrm{Z}_{\mathrm{CiH}}{ }^{\prime} \beta_{\mathrm{C}}+\mathrm{u}_{\mathrm{CiH}}$ $\mathrm{i}=1, . ., \mathrm{N}_{\mathrm{CH}}$

where $\phi_{\mathrm{P}}=\theta_{2 \mathrm{P}} /\left(\theta_{1 \mathrm{C}}+\theta_{2 \mathrm{C}}\right), \phi_{\mathrm{C}}=\theta_{2 \mathrm{C}} /\left(\theta_{1 \mathrm{C}}+\theta_{2 \mathrm{C}}\right), \beta_{\mathrm{C}}=\theta_{1 \mathrm{C}} \gamma_{1}$, and $\mathrm{u}_{\mathrm{CiH}}=\mathrm{m}_{\mathrm{CiH}^{+}}+\theta_{1 \mathrm{C}} \mathrm{f}_{\mathrm{CiH}}-\phi_{\mathrm{C}} \mathrm{m}_{\mathrm{CH}}, \mathrm{u}_{\mathrm{PH}}=\mathrm{m}_{\mathrm{PH}}+$ $\theta_{1 \mathrm{PWPH}}-\phi_{\mathrm{P}} \mathrm{m}_{\mathrm{CH}}$.

Equation (A4.1) suggests the null hypothesis $\phi_{\mathrm{P}}=0$ (or, which is the same, $\theta_{2 \mathrm{P}}=0$ ) can be tested by running a regression of parents' participation status $d_{\mathrm{PH}}$ on the average participation rate of children on the household $\mathrm{d}_{\mathrm{CH}}$. For children, equation (A.4.2) suggests that the null hypothesis $\phi_{\mathrm{C}}=0$ (or, which is the same, $\left.\theta_{2 \mathrm{C}}=0\right)$ can be tested by running a regression of each child's individual participation $\left(\mathrm{d}_{\mathrm{CiH}}\right)$ on the individual value of $\mathrm{Z}_{\mathrm{CiH}}$ and the average participation rate of children in the household $\left(\mathrm{d}_{\mathrm{CH}}\right)$, including the child whose labor supply we are trying to explain. 
Equations (A4.1) and (A4.2) constitute the basis of my empirical analysis (respectively equations (2) and (4) in the text). ${ }^{53}$

\footnotetext{
${ }^{53}$ Typically, when $\mathrm{d}_{\mathrm{jH}}$ 's is a $0 / 1$ variable, the term $\mathrm{E}_{\mathrm{CH}}{ }^{*}$ is evaluated at $\mathrm{d}_{\mathrm{jH}}=0$ for the individual whose labor supply is measured on the left hand side. In this case, equation (A.2.2) would suggest running a regression of each individual child's participation on the potential income the child's siblings (plus the other covariates) rather than the potential income of all the children in the household. The reason that is generally invoked for this approximation is that, at zero hours of work, there is no income effect arising from changes in the individual's wage. Obviously, this is not less arbitrary than evaluating this term at $\mathrm{d}_{\mathrm{jH}}=1$. There are at least two reasons why in this paper I use an approximation around $\mathrm{d}_{\mathrm{jH}}=1$ even for the individual whose labor supply I am trying to explain. First, since I approximate the labor supply of every other individual at $\mathrm{d}_{\mathrm{jH}}=1$, it seems coherent to use the same approximation for the individual in question. A second reason for this is that if the labor supply of one child depends on the earnings of his siblings, the model does generate the simple externality as in (A.4.2).
} 
Table 1

Children's labor force status by age and gender

\begin{tabular}{|c|c|c|c|c|c|c|c|c|c|c|}
\hline \multirow[b]{3}{*}{ Age } & \multicolumn{10}{|c|}{ BOYS } \\
\hline & \multicolumn{3}{|c|}{ work } & \multirow[t]{2}{*}{ school } & \multicolumn{4}{|c|}{ school and work } & \multirow{2}{*}{$\begin{array}{c}>=\text { work } \\
\text { age }\end{array}$} & \multirow{2}{*}{ 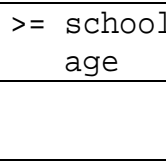 } \\
\hline & total & market & $\mathrm{HH}$ farm & & work only & $\begin{array}{c}\text { school } \\
\text { only }\end{array}$ & $\begin{array}{c}\text { school and } \\
\text { work }\end{array}$ & idle & & \\
\hline 10 & 2.87 & 0.49 & 2.38 & 94.41 & 0.35 & 91.89 & 2.52 & 5.24 & 3.21 & 0.00 \\
\hline 11 & 3.80 & 0.55 & 3.26 & 94.65 & 0.57 & 91.41 & 3.23 & 4.78 & 3.64 & 0.00 \\
\hline 12 & 6.30 & 1.16 & 5.14 & 94.58 & 0.93 & 89.22 & 5.37 & 4.48 & 20.31 & 1.94 \\
\hline 13 & 7.92 & 1.88 & 6.04 & 94.02 & 1.66 & 87.77 & 6.26 & 4.32 & 21.43 & 2.16 \\
\hline 14 & 14.73 & 6.05 & 8.68 & 88.95 & 4.34 & 78.56 & 10.39 & 6.71 & 93.06 & 20.62 \\
\hline 15 & 24.89 & 14.98 & 9.91 & 76.07 & 13.75 & 64.93 & 11.14 & 10.18 & 100.00 & 29.90 \\
\hline 16 & 44.27 & 31.55 & 12.72 & 54.41 & 32.27 & 42.41 & 12.00 & 13.32 & 100.00 & 100.00 \\
\hline Total & 10.68 & 4.98 & 5.69 & 89.29 & 4.63 & 83.24 & 6.05 & 6.08 & 34.86 & 13.00 \\
\hline
\end{tabular}

GIRLS

\begin{tabular}{|c|c|c|c|c|c|c|c|c|c|}
\hline \multicolumn{3}{|c|}{ work } & \multirow[t]{2}{*}{ school } & \multicolumn{4}{|c|}{ school and work } & $>=$ work & $>=$ school \\
\hline total & market & $\mathrm{HH}$ farm & & work only & $\begin{array}{c}\text { school } \\
\text { only }\end{array}$ & $\begin{array}{c}\text { school and } \\
\text { work }\end{array}$ & idle & & \\
\hline 1.59 & 0.15 & 1.44 & 94.80 & 0.36 & 93.57 & 1.23 & 4.84 & 4.06 & 0.00 \\
\hline 1.76 & 0.15 & 1.61 & 95.66 & 0.35 & 94.25 & 1.41 & 3.99 & 3.52 & 0.00 \\
\hline 2.95 & 0.44 & 2.52 & 95.02 & 0.69 & 92.76 & 2.26 & 4.29 & 20.83 & 2.16 \\
\hline 3.27 & 0.45 & 2.82 & 94.27 & 0.52 & 91.52 & 2.75 & 5.21 & 22.44 & 2.46 \\
\hline 6.03 & 3.39 & 2.64 & 89.08 & 2.64 & 85.69 & 3.39 & 8.29 & 93.07 & 18.61 \\
\hline 11.70 & 7.87 & 3.83 & 79.62 & 7.17 & 75.09 & 4.53 & 13.21 & 100.00 & 30.89 \\
\hline 26.72 & 22.88 & 3.83 & 58.50 & 21.52 & 53.31 & 5.19 & 19.98 & 100.00 & 100.00 \\
\hline 5.35 & 2.97 & 2.38 & 90.26 & 2.86 & 87.76 & 2.50 & 6.89 & 35.58 & 13.00 \\
\hline
\end{tabular}

Notes. The Table reports the distribution of children's work by age and gender. The first column refers to total work, irrespective of whether performed in the market or not. The second column excludes those working on the household farm, whose proportion is reported in the third column. The fourth column refers to those working but not enrolled in school. The fifth refers to those enrolled in school but not working. The sixth column refers to those both working and enrolled in school and the seventh column to those neither working nor enrolled in school (idle). The last two columns report respectively the proportion of children at or above legal working age and the proportion of children at or above school leaving age in their state of residence. Sample refers to children aged 10-16 living with both parents, with mother aged 2541, father aged 25-66, and with no other household members other than the father, the mother and siblings aged 0 to 16 . Number of observations: 44,402. 
Table 2

Parents' labor force status by children's labor force status and average age

\begin{tabular}{lccc}
\hline \multirow{2}{*}{$\begin{array}{l}\text { Average } \\
\text { children's age }\end{array}$} & $\begin{array}{c}\text { no working } \\
\text { children }\end{array}$ & $\begin{array}{c}\text { at least one } \\
\text { working } \\
\text { child }\end{array}$ & total \\
\cline { 2 - 4 } 10 & 99.020 & 98.925 & 99.018 \\
11 & 99.121 & 100.000 & 99.151 \\
12 & 98.745 & 98.986 & 98.767 \\
13 & 98.492 & 99.778 & 98.729 \\
14 & 98.834 & 98.994 & 98.866 \\
15 & 98.973 & 99.270 & 99.043 \\
16 & 97.783 & 99.048 & 98.185 \\
Total & 98.850 & 99.353 & 98.903 \\
\hline
\end{tabular}

\begin{tabular}{lccc}
\multirow{2}{*}{$\begin{array}{l}\text { Average } \\
\text { children's age }\end{array}$} & $\begin{array}{c}\text { MOTHERS } \\
\text { no working } \\
\text { children }\end{array}$ & $\begin{array}{c}\text { at least one } \\
\text { working } \\
\text { child }\end{array}$ & total \\
10 & 5.271 & 44.086 & 6.042 \\
11 & 5.239 & 31.481 & 6.130 \\
12 & 5.382 & 23.142 & 7.022 \\
13 & 5.304 & 13.333 & 6.786 \\
14 & 6.694 & 16.700 & 8.708 \\
15 & 6.621 & 16.423 & 8.957 \\
16 & 7.539 & 21.905 & 12.103 \\
Total & 5.506 & 19.410 & 6.959 \\
\hline
\end{tabular}

Notes. The Table reports the parents' probability of work (whether in the market or on the household farm) by the average age of children between 10 and 16 in the household (approximated to the lowest integer). The first column refers to households with no working children, the second to households with at least one working child and the third to all households irrespective of their children's labor force status. For sample selection see Notes to Table 1 . Number of observations 26,612 . 
Table 3

Individuals' top-5 market jobs

\begin{tabular}{llc}
\hline & BOYS & \\
\hline Occupation & Industry & \multicolumn{1}{c}{} \\
\hline & & \\
Farm laborers, wage workers & Agriculture & 0.107 \\
Mine operatives and laborers & Coal mining & 0.044 \\
Newsboys & Printing, publishing & 0.042 \\
Newsboys & Misc. retail stores & 0.039 \\
Operative and kindred workers & Yarn, thread, and fabric & 0.027 \\
\hline
\end{tabular}

GIRLS

\begin{tabular}{lll}
\hline Occupation & Industry & \% \\
\hline & & \\
Operative and kindred workers & Yarn, thread, and fabric & 0.069 \\
Operative and kindred workers & Apparel and accessories & 0.058 \\
Farm laborers, wage workers & Agriculture & 0.054 \\
Private household workers & Private households & 0.054 \\
Salesmen and sales clerks & General merchandise & 0.032 \\
\hline
\end{tabular}

FATHERS

\begin{tabular}{llc}
\hline Occupation & Industry & $\frac{0}{0}$ \\
\hline & & 0.049 \\
Farm laborers, wage workers & Agriculture & 0.039 \\
Mine operatives and laborers & Coal mining & 0.035 \\
Carpenters & Construction & 0.020 \\
Laborers & Railroads and railway \\
Managers, and proprietors & Food stores, except dairy & 0.019 \\
\hline
\end{tabular}

\begin{tabular}{lll} 
& MOTHERS & \\
\hline Occupation & Industry & $\%$ \\
Laundresses & & 0.140 \\
Farm laborers, wage workers & Private households & 0.089 \\
Private household workers & Priculture & 0.064 \\
Dressmakers and seamstresses & Dressmaking shops & 0.055 \\
Operative and kindred workers & Apparel and accessories & 0.033 \\
\hline
\end{tabular}

Notes. The Table reports the most frequent jobs (occupation and industry) with the associated frequencies among those performing market work. See notes to Table 1 and 2 . 
Table 4

The effect of child labor laws on children's labor supply Individual level estimates

\begin{tabular}{|c|c|c|c|c|c|c|c|}
\hline \multirow{2}{*}{ 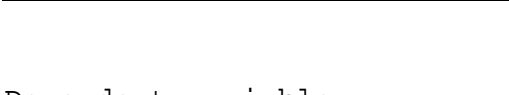 } & \multicolumn{6}{|c|}{ Legal working age } & \multirow[b]{2}{*}{15} \\
\hline & 0 & 7 & 8 & 12 & 13 & 14 & \\
\hline$\frac{\text { 1. Total work }}{\text { no controls }}$ & $\begin{array}{l}0.025 * \star \\
(0.012)\end{array}$ & $\begin{array}{l}0.039 \star \star \\
(0.011)\end{array}$ & $\begin{array}{l}0.051 * \star \\
(0.009)\end{array}$ & $\begin{array}{l}0.044 \star \star \\
(0.004)\end{array}$ & $\begin{array}{l}0.089 \star \star \\
(0.012)\end{array}$ & $\begin{array}{l}0.099 \star \star \\
(0.009)\end{array}$ & $\begin{array}{l}0.128 * \star \\
(0.017)\end{array}$ \\
\hline $\begin{array}{l}\frac{2 . \text { Total work }}{\text { individual child controls }} \\
\text { and HH controls }\end{array}$ & $\begin{array}{l}0.025 * \star \\
(0.013)\end{array}$ & $\begin{array}{l}0.036 \star \star \\
(0.010)\end{array}$ & $\begin{array}{l}0.049 \star \star \\
(0.009)\end{array}$ & $\begin{array}{l}0.043 \star \star \\
(0.004)\end{array}$ & $\begin{array}{l}0.091 \star \star \\
(0.014)\end{array}$ & $\begin{array}{l}0.100 * \star \\
(0.009)\end{array}$ & $\begin{array}{l}0.128 * \star \\
(0.018)\end{array}$ \\
\hline $\begin{array}{l}\text { 3. Total work } \\
\text { individual child controls } \\
\text { and HH fixed effects }\end{array}$ & $\begin{array}{c}0.009 \\
(0.008)\end{array}$ & $\begin{array}{l}0.042 \star \star \\
(0.011)\end{array}$ & $\begin{array}{l}0.052 * \star \\
(0.008)\end{array}$ & $\begin{array}{l}0.041 \star \star \\
(0.006)\end{array}$ & $\begin{array}{l}0.103 * \star \\
(0.018)\end{array}$ & $\begin{array}{l}0.105 \star \star \\
(0.013)\end{array}$ & $\begin{array}{l}0.143 * \star \\
(0.029)\end{array}$ \\
\hline $\begin{array}{l}\text { 4. Market work } \\
\text { individual child controls } \\
\text { and HH controls }\end{array}$ & $\begin{array}{l}0.026 \star \\
(0.014)\end{array}$ & $\begin{array}{l}0.027 * \star \\
(0.008)\end{array}$ & $\begin{array}{l}0.027 * * \\
(0.006)\end{array}$ & $\begin{array}{l}0.022 * \star \\
(0.003)\end{array}$ & $\begin{array}{l}0.088 * \star \\
(0.013)\end{array}$ & $\begin{array}{l}0.094 * \star \\
(0.011)\end{array}$ & $\begin{array}{l}0.127 \star \star \\
(0.019)\end{array}$ \\
\hline $\begin{array}{l}\text { 5. Work in HH farm } \\
\text { individual child controls } \\
\text { and HH controls }\end{array}$ & $\begin{array}{l}-0.001 \\
(0.005)\end{array}$ & $\begin{array}{l}0.010 * \star \\
(0.003)\end{array}$ & $\begin{array}{l}0.022 * \star \\
(0.004)\end{array}$ & $\begin{array}{l}0.021 \star \star \\
(0.003)\end{array}$ & $\begin{array}{c}0.003 \\
(0.002)\end{array}$ & $\begin{array}{l}0.005 \star \\
(0.003)\end{array}$ & $\begin{array}{c}0.001 \\
(0.004)\end{array}$ \\
\hline $\begin{array}{l}\frac{\text { 6. School }}{\text { individual child controls }} \\
\text { and HH controls }\end{array}$ & $\begin{array}{l}-0.038 \\
(0.023)\end{array}$ & $\begin{array}{c}-0.044 * \star \\
(0.015)\end{array}$ & $\begin{array}{c}-0.037 * \star \\
(0.014)\end{array}$ & $\begin{array}{c}-0.045 * \star \\
(0.005)\end{array}$ & $\begin{array}{l}-0.126 * \star \\
(0.015)\end{array}$ & $\begin{array}{c}-0.131 * \star \\
(0.010)\end{array}$ & $\begin{array}{c}-0.213 * * \\
(0.012)\end{array}$ \\
\hline
\end{tabular}

Notes. The Table reports child level OLS estimates of equation (1). The reported coefficients are child level estimates of the effect of $\mathrm{Z}_{\mathrm{CiH}}$ on child labor. $\mathrm{Z}_{\mathrm{CiH}}$ is defined as the difference between the child's age and the maximum age at which a child is not allowed to work in his state of residence (legal working age minus 1 ). The coefficient on $\mathrm{Z}_{\mathrm{ciH}}$ is allowed to vary by legal working age. Clustered standard errors (by State and child's age) in parentheses. * Significant at 10\%; $\star$ significant at $5 \%$. Individual child controls include a linear term in age, a gender dummy and a linear term in the child's order of birth. Household controls include dummies for number of children $10-16$ (from 1 to 6 or more), the proportion of male children 10-16, the average age of children aged 10-16, the number of children aged 0-9, the proportion of children age 0 to 9 in each age group (from 0 to 9), an urban dummy, a dummy for whether the household lives on a farm, three dummies for home ownership (owned and not mortgaged, mortgaged, rented), two dummies equal to one if the father or the mother are immigrants, three dummies for parents' race (white, black and other), two dummies equal to one if the father or the mother are illiterate, father's and mother's age and age squared. All regressions control for State fixed effects. Number of observations 44,402. See also notes to Table 1. 
Table 5

The effect of child labor laws on children's market work Household level estimates

\begin{tabular}{|c|c|c|c|c|c|c|c|}
\hline \multicolumn{7}{|c|}{ Legal working age } & \multirow[b]{2}{*}{$\begin{array}{l}\text { [F-test] } \\
\text { (p-value) }\end{array}$} \\
\hline 0 & 7 & 8 & 12 & 13 & 14 & 15 & \\
\hline
\end{tabular}

\section{Dependent variable}

\begin{tabular}{|c|c|c|c|c|c|c|c|c|}
\hline$\frac{\text { 1. Market work }}{\text { no HH controls }}$ & $\begin{array}{l}0.036 \\
(0.023)\end{array}$ & $\begin{array}{l}0.026 \star \star \\
(0.005)\end{array}$ & $\begin{array}{l}0.033 \star \star \\
(0.015)\end{array}$ & $\begin{array}{l}0.022 * \star \\
(0.004)\end{array}$ & $\begin{array}{l}0.081 * \star \\
(0.019)\end{array}$ & $\begin{array}{l}0.091 * \star \\
(0.006)\end{array}$ & $\begin{array}{l}0.116 * * \\
(0.013)\end{array}$ & $\begin{array}{l}34.129 \\
(0.000)\end{array}$ \\
\hline$\frac{\text { 2. Market work }}{\mathrm{HH} \text { controls }}$ & $\begin{array}{l}0.037 \star \\
(0.022)\end{array}$ & $\begin{array}{l}0.025 * \star \\
(0.005)\end{array}$ & $\begin{array}{l}0.032 * \star \\
(0.014)\end{array}$ & $\begin{array}{l}0.021 * \star \\
(0.003)\end{array}$ & $\begin{array}{l}0.081 * \star \\
(0.019)\end{array}$ & $\begin{array}{l}0.091 * \star \\
(0.006)\end{array}$ & $\begin{array}{l}0.117 * \star \\
(0.012)\end{array}$ & $\begin{array}{l}35.112 \\
(0.000)\end{array}$ \\
\hline
\end{tabular}

Notes. The Table reports household level OLS estimates of equation (3). The reported coefficients are estimates of the effect of $\mathrm{Z}_{\mathrm{CH}}$ on the proportion of children working in the market. $\mathrm{Z}_{\mathrm{CH}}$ is defined as the average difference between children's age and the maximum age at which they are not allowed to work in their state of residence (legal working age minus 1 ). Ftest is a test for the joint validity of the instruments. Number of observations 26,612. Degrees of freedom of F-test (7, 335). See also notes to Table 2 and 4. 
Table 6

The effect of children's market work on household labor supply

\begin{tabular}{|c|c|c|c|c|c|c|}
\hline \multirow[b]{2}{*}{ Method of estimation } & \multicolumn{2}{|c|}{ Father } & \multicolumn{2}{|c|}{ Mother } & \multicolumn{2}{|c|}{ Children } \\
\hline & OLS & $2 S L S$ & OLS & 2SLS & OLS & $2 S L S$ \\
\hline Dependent variable & & & & & & \\
\hline 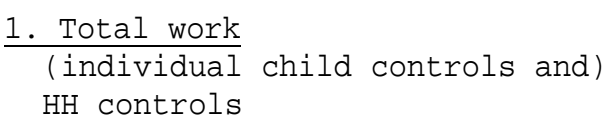 & $\begin{array}{l}0.008 * \\
(0.004)\end{array}$ & $\begin{array}{l}0.004 \\
(0.022)\end{array}$ & $\begin{array}{l}0.113 * * \\
(0.016)\end{array}$ & $\begin{array}{l}-0.015 \\
(0.049)\end{array}$ & $\begin{array}{l}0.919 * * \\
(0.041)\end{array}$ & $\begin{array}{l}-0.164 * * \\
(0.075)\end{array}$ \\
\hline $\begin{array}{l}\text { [Overid. test] } \\
\text { (p-value) }\end{array}$ & & $\begin{array}{l}{[6.470]} \\
(0.373)\end{array}$ & & $\begin{array}{l}{[11.878]} \\
(0.065)\end{array}$ & & $\begin{array}{l}{[4.008]} \\
(0.676)\end{array}$ \\
\hline $\begin{array}{l}\text { 2. School } \\
\text { (individual child controls and) } \\
\text { HH controls }\end{array}$ & & & & & $\begin{array}{l}-0.451 * \star \\
(0.038)\end{array}$ & $\begin{array}{l}0.131 \star \\
(0.076)\end{array}$ \\
\hline $\begin{array}{l}\text { [Overid. test] } \\
(\mathrm{p} \text {-value) }\end{array}$ & & & & & & $\begin{array}{c}2.553 \\
(0.863)\end{array}$ \\
\hline $\begin{array}{l}\frac{\text { 3. Idleness }}{\text { (individual child controls and) }} \\
\text { HH controls }\end{array}$ & $\begin{array}{l}-0.008 * \\
(0.004)\end{array}$ & $\begin{array}{l}-0.003 \\
(0.022)\end{array}$ & $\begin{array}{l}-0.112 * \star \\
(0.016)\end{array}$ & $\begin{array}{l}0.006 \\
(0.049)\end{array}$ & $\begin{array}{l}-0.139 * \star \\
(0.015)\end{array}$ & $\begin{array}{l}-0.025 \\
(0.064)\end{array}$ \\
\hline $\begin{array}{l}\text { [Overid. test] } \\
\text { (p-value) }\end{array}$ & & $\begin{array}{l}{[6.463]} \\
(0.373)\end{array}$ & & $\begin{array}{l}{[12.309]} \\
(0.055)\end{array}$ & & $\begin{array}{l}{[0.745]} \\
(0.993)\end{array}$ \\
\hline
\end{tabular}

Notes. The Table reports individual level estimates of equations (2) and (4). The reported coefficients are the estimated effects of the proportion of children working in the market in each household d $\mathrm{d}_{\mathrm{CH}}$ on parents' and children's labor supply. For each household member (Father, Mother and Children) the Table reports oLS estimates in the first column and 2SLS estimates in the second column. 2SLS estimates are obtained by instrumenting $\mathrm{d}_{\mathrm{CH}}$ based on the specification estimated in Table 5, row 2. All regressions include household controls (as in Table 5) and State fixed effects. Regressions for children include individual children controls (as in Table 4) plus controls for the difference between the child's age and the maximum age at which work is not allowed in the state of residence, whose effect is allowed to work by minimum working age. Overid. test is the over-identification test for the internal consistency of the instruments. The statistic is distributed as a Chi-square with six degree of freedom. Number of observations for fathers' and mothers' regressions: 26,612 . Number of observations for the children's regressions: 44,402. See also notes to Tables 3,4 and 5. 
Table 7

The effect of children's market work on household labor supply - 2SLS estimates Robustness checks

\begin{tabular}{|c|c|c|c|}
\hline \multirow[b]{2}{*}{ Dependent variable } & Father & Mother & Children \\
\hline & & & \\
\hline 1. Total work -State specific age profiles & $\begin{array}{c}0.007 \\
(0.023)\end{array}$ & $\begin{array}{c}0.031 \\
(0.051)\end{array}$ & $\begin{array}{r}-0.123 * \\
(0.073)\end{array}$ \\
\hline $\begin{array}{l}\text { [Overid. test] } \\
\text { (p-value) }\end{array}$ & $\begin{array}{l}{[4.659]} \\
(0.588)\end{array}$ & $\begin{array}{l}{[8.154]} \\
(0.227)\end{array}$ & $\begin{array}{l}{[3.425]} \\
(0.331)\end{array}$ \\
\hline 2. Total work -States with Compulsory school age 16 & $\begin{array}{l}0.006 \\
(0.024)\end{array}$ & $\begin{array}{l}-0.025 \\
(0.048)\end{array}$ & $\begin{array}{r}-0.124 * \\
(0.068)\end{array}$ \\
\hline $\begin{array}{l}\text { [Overid. test] } \\
\text { (p-value) }\end{array}$ & $\begin{array}{l}{[0.392]} \\
(0.822)\end{array}$ & $\begin{array}{l}{[10.083]} \\
(0.006)\end{array}$ & $\begin{array}{l}{[1.240]} \\
(0.538)\end{array}$ \\
\hline 3a. Total work - effect of boys' market work & $\begin{array}{l}-0.006 \\
(0.037)\end{array}$ & $\begin{array}{l}-0.108 \\
(0.078)\end{array}$ & $\begin{array}{r}-0.197 \star \\
(0.113)\end{array}$ \\
\hline 3b. Total work - effect of girls' market work & $\begin{array}{l}0.014 \\
(0.027)\end{array}$ & $\begin{array}{l}0.038 \\
(0.060)\end{array}$ & $\begin{array}{r}-0.135 * \\
(0.080)\end{array}$ \\
\hline $\begin{array}{l}\text { [Overid. test] } \\
\text { (p-value) }\end{array}$ & $\begin{array}{l}{[9.728]} \\
(0.640)\end{array}$ & $\begin{array}{l}{[18.470]} \\
(0.102)\end{array}$ & $\begin{array}{l}{[11.583]} \\
(0.480)\end{array}$ \\
\hline 4. Market work & $\begin{array}{l}0.058 \\
(0.041)\end{array}$ & $\begin{array}{l}-0.003 \\
(0.047)\end{array}$ & $\begin{array}{l}-0.083 \\
(0.072)\end{array}$ \\
\hline $\begin{array}{l}\text { [Overid. test] } \\
\text { (p-value) }\end{array}$ & $\begin{array}{l}{[2.059]} \\
(0.914)\end{array}$ & $\begin{array}{l}{[6.657]} \\
(0.354)\end{array}$ & $\begin{array}{l}{[2.575]} \\
(0.860)\end{array}$ \\
\hline 5. Work in $\mathrm{HH}$ farm & $\begin{array}{l}-0.054 \\
(0.036)\end{array}$ & $\begin{array}{l}-0.012 \\
(0.019)\end{array}$ & $\begin{array}{l}-0.081 * \star \\
(0.035)\end{array}$ \\
\hline $\begin{array}{l}\text { [Overid. test] } \\
\text { (p-value) }\end{array}$ & $\begin{array}{l}{[1.872]} \\
(0.931)\end{array}$ & $\begin{array}{l}{[9.698]} \\
(0.138)\end{array}$ & $\begin{array}{l}{[6.338]} \\
(0.386)\end{array}$ \\
\hline 6. Total work - One-child households & $\begin{array}{l}0.007 \\
(0.028)\end{array}$ & $\begin{array}{l}0.023 \\
(0.059)\end{array}$ & \\
\hline $\begin{array}{l}\text { [Overid. test] } \\
\text { (p-value) }\end{array}$ & $\begin{array}{l}{[3.930]} \\
(0.686)\end{array}$ & $\begin{array}{l}{[8.667]} \\
(0.193)\end{array}$ & \\
\hline
\end{tabular}

Notes. The Table reports the 2SLS estimates of equations (2) and (4) as in Table 6 . The regressions include the same controls as in Table 6. Specification 1 controls additionally for the interaction of the following variables with State dummies: father's and mother's age and age squared, average age of children 10-16, child's age (this variable only in the children's regressions). Specification 2 restricts to states with a compulsory schooling age of 16 . Specification 3 allows for a different effect of boys' and girls' market work on household labor supply. Boys' and girls' labor supply is measured as the number of working boys and girls over the total number of children. Regressions control, additionally, for the average age of boys and girls, and the number of boys and girls in the household. Regressions for children include additionally the interaction of the child's age with a gender dummy and the interaction of the effect of child labor laws with a gender dummy. Rows 4 and 5 look separately at the effect of children's market work on individuals' work in the market and on the farm. Row 6 restricts to households with only one child aged 10 to 16 . See also notes to Table 6 . 
Table A1

Probability of having a child born before 1904 in 1910 and 1920 among mothers with children born between 1904 and 1910 .

\begin{tabular}{|c|c|c|c|c|}
\hline \multirow[t]{2}{*}{$\begin{array}{l}\text { Mother } \\
\text { birth } \\
\text { cohort }\end{array}$} & \multirow[t]{2}{*}{$\begin{array}{l}\text { Mother age } \\
\text { in } 1920\end{array}$} & \multicolumn{2}{|c|}{$\begin{array}{c}\text { cumulative of mothers } \\
\text { with one child born } \\
\text { before } 1904\end{array}$} & \multirow{2}{*}{$\begin{array}{l}\text { Difference } \\
1920-1910\end{array}$} \\
\hline & & 1910 & 1920 & \\
\hline 1885 & 35 & 17.833 & 14.632 & 3.202 \\
\hline 1884 & 36 & 21.307 & 16.850 & 4.457 \\
\hline 1883 & 37 & 24.647 & 19.593 & 5.055 \\
\hline 1882 & 38 & 29.284 & 23.240 & 6.044 \\
\hline 1881 & 39 & 32.836 & 26.446 & 6.390 \\
\hline 1880 & 40 & 37.029 & 30.173 & 6.856 \\
\hline 1879 & 41 & 39.569 & 32.430 & 7.140 \\
\hline 1878 & 42 & 42.980 & 35.315 & 7.665 \\
\hline 1877 & 43 & 45.915 & 37.384 & 8.530 \\
\hline 1876 & 44 & 48.464 & 39.356 & 9.108 \\
\hline 1875 & 45 & 51.037 & 41.607 & 9.431 \\
\hline 1874 & 46 & 53.241 & 43.255 & 9.986 \\
\hline 1873 & 47 & 55.053 & 44.736 & 10.317 \\
\hline 1872 & 48 & 57.042 & 46.181 & 10.862 \\
\hline 1871 & 49 & 58.397 & 47.338 & 11.059 \\
\hline 1870 & 50 & 59.793 & 48.458 & 11.335 \\
\hline
\end{tabular}

Notes. The Table reports the cumulative probability of having at least one cohabiting child born before 1904 (i.e. older than 16 in 1920) among women born after 1869 (i.e. younger than 51 in 1920) with at least one cohabiting child born between 1904 and 1910 (i.e. aged 10 to 16 in 1920). The Table reports this distribution in 1910 and in 1920. 
Figure 1

Child labor by age and minimum legal working age: actual and estimated

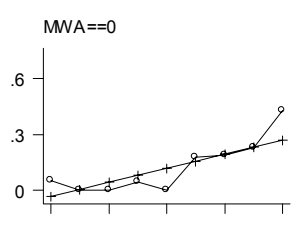

MNA $==12$

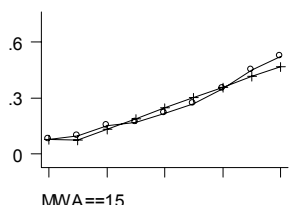

$M W A==15$

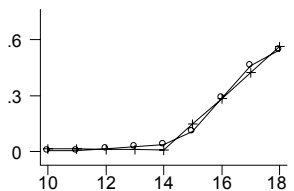

$M N A==7$

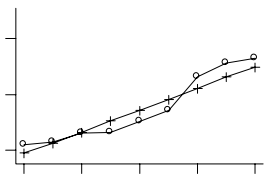

$M N A==13$

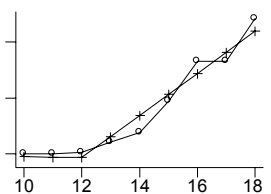

$M N A==8$

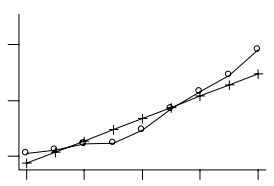

$M W A==14$

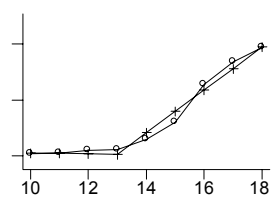

Notes. The Figure reports the proportion of working children by age in seven groups of states classified based on legal working age (MWA). I have superimposed to the actual participation profiles a linear spline with a kink at the age just below legal working age (legal working age minus one). 


\section{Figure A1}

Labor force participation by age in states with minimum legal working age 12 and 14

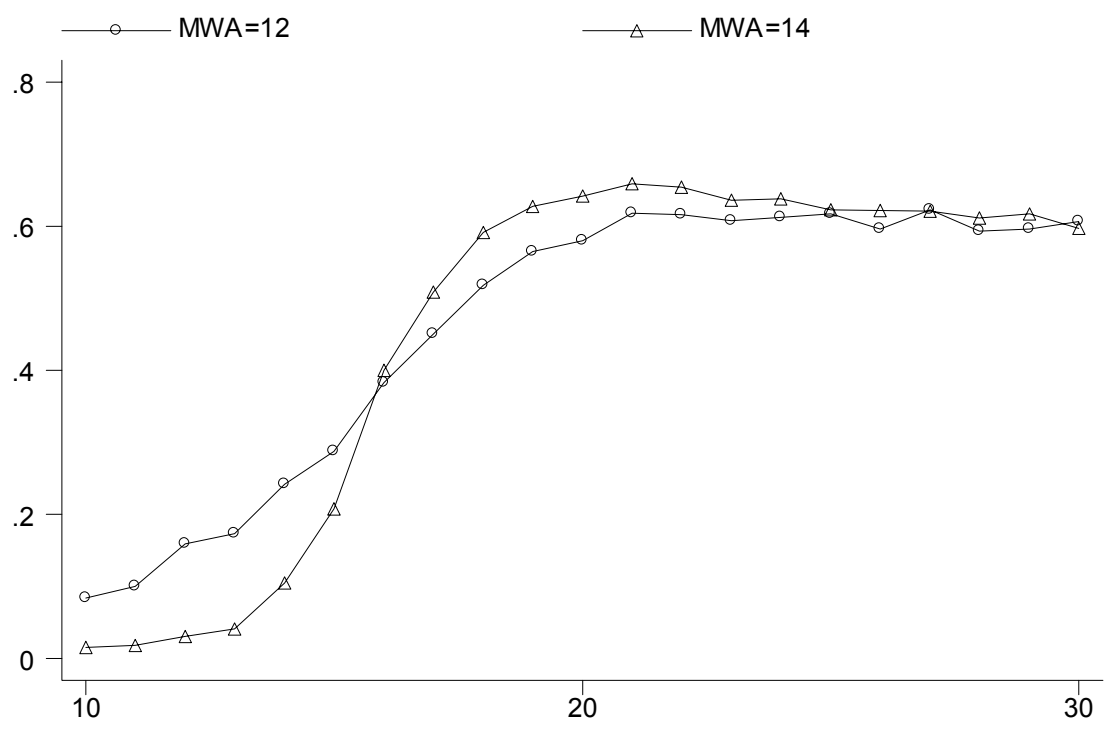

Notes. See notes to Figure 1. 


\section{CENTRE FOR ECONOMIC PERFORMANCE \\ Recent Discussion Papers}

589 Alex Bryson

Rafael Gomez

588 Henry G. Overman

L. Alan Winters

587 Pierre-Philippe Combes Henry G. Overman

586 Henry G. Overman

585 A. B. Bernard

J. Bradford Jensen

P. K. Schott

584 A. B. Bernard

J. Bradford Jensen

P. K. Schott

583 S. Wood

S. Moore

582 T. Kirchmaier

581 C. Dougherty

580 S. Burgess

D. Mawson

579 S. Nickell

578 D. Marsden

577 S. Nickell
Why Have Workers Stopped Joining Unions?

Trade Shocks and Industrial Location: the Impact of EEC Accession on the UK

The Spatial Distribution of Economic Activities in the European Union

Can We Learn Anything from Economic Geography Proper?

Falling Trade Costs, Heterogeneous Firms and Industry Dynamics

Survival of the Best Fit: Exposure to Low-Wage Countries and the (Uneven) Growth of U.S.

Manufacturing Plants

Reviewing the Statutory Union Recognition (ERA 1999)

Corporate Restructuring and Firm Performance of British and German Non-Financial Firms

Why Is the Rate of Return to Schooling Higher for Women than for Men?

Aggregate Growth and the Efficiency of Labour Reallocation

Poverty and Worklessness in Britain

Renegotiating Performance: the Role of Performance Pay in Renegotiating the Effort Bargain

A Picture of European Unemployment: Success and Failure 
576 A. de Coulon

M. Piracha

575 H. Steedman

K. Wagner

J. Foreman

574 S. Gibbons

573 R. Griffith

S. Redding

H. Simpson

$572 \quad$ S. Redding

P. K. Schott

571 B. Petrongolo

C. A. Pissarides

570 M. Coles

B. Petrongolo

569 A. Bryson

L. Cappellari

C. Lucifora

568 A. Bryson

R. Gomez

567 M. Gutiérrez-Domènech

566 T. Kirchmaier

565 P. Lopez-Garcia

564 A. Manning
Self-Selection and the Performance of Return Migrants: the Source Country Perspective

The Impact on Firms of ICT Skill-Supply Strategies:

An Anglo-German Comparison

The Costs of Urban Property Crime

Productivity Convergence and Foreign Ownership at the Establishment Level

Distance, Skill Deepening and Development: Will Peripheral Countries Ever Get Rich?

Scale Effects in Markets with Search

A Test Between Unemployment Theories Using Matching Data

Does Union Membership Really Reduce Job Satisfaction?

Segmentation, Switching Costs and the Demand for Unionization in Britain

Employment After Motherhood: AEuropean

Comparison

The Performance Effects of European Demergers

Labour Market Performance and Start-Up Costs: OECD Evidence

The Real Thin Theory: Monopsony in Modern Labour Markets 